\title{
A LIBERDADE DE MANIFESTAÇÃO DO PENSAMENTO ${ }^{1}$
}

\author{
FREEDOM OF EXPRESSION
}

\author{
MICHELA MANETTI ${ }^{2}$
}

\begin{abstract}
RESUMO: O objetivo do presente estudo é proceder a uma análise do princípio da liberdade de manifestação do pensamento, sua evolução histórica e sua importância como garantia da existência de um Estado democrático. Também são objeto de exame os princípios que derivam da liberdade de manifestação do pensamento e que, muitas vezes, com ele colidem, devendo-se aferir como se consegue o equilíbrio entre eles, bem como a garantia ao pluralismo nos meios de comunicação. O tema será analisado sob a ótica das regras específicas da Constituição Italiana, assim como da jurisprudência da Corte Constitucional da Itália. PALAVRAS-CHAVE: Liberdade de Manifestação do Pensamento; Liberdade de Imprensa; Pluralismo; Informação.
\end{abstract}

ABSTRACT: The goal of this study is to do a review of freedom of thought, its historical evolution and its importance as a guarantee of the existence of a democratic State. They are also subject to analysis the principles that derive from the freedom of thought and often collide with it, to check how they could be balanced, as well as ensuring pluralism in the media. The theme will be analyzed from the perspective of the rules of Italian Constitution, as well as the jurisprudence of the Constitutuional Court of Italy.

KEYWORDS: Freedom of Thougt; Free Press; Pluralism; Information.

SUMÁRIO: 1. Introdução; 2. Evolução dos Meios e do Público ao qual é destinada a Manifestação do Pensamento; 3. Problemáticas Clássicas da Liberdade de Pensamento; 4. Problemáticas Contemporâneas da Liberdade de Pensamento; 5. A Constituição Italiana; 6. A Atuação da Constituição; 7. A Reconstrução da Garantia Constitucional; 8. Âmbito Subjetivo da Garantia Constitucional; Referências Bibliográficas.

SUMMARY: 1. Introduction; 2. The Evolution of the Means and Publicity of Thought; 3. Classic Free Speech Issues; 4. Contemporary Free Speech Issues; 5. The Italian Constitution; 6. The Constitutional Law Aspects; 7. The Reconstruction of the Constitutional Guarantee; 8. The Subjective Right Protective Scope of the Constitutional Guarantee; References.

\footnotetext{
Artigo recebido em 02.12.2012. Artigo aceito para publicação em 23.06.2013 mediante convite.

${ }^{1}$ Tradução por Rodrigo Koehler Ribeiro, Mestrando pela PUCRS e Juiz Federal. Referência da Publicação Original: MANETTI, M. La Liberta di Manifestazione del Pensiero. In: NANIA, Roberto; RIDOLA, Paolo (Org.). I Diritti Costituzionali, v. II, 2. ed., rev. e amp., Turim: Giappinchelli, 2006, p. 767-823.

${ }^{2}$ Professora de Direito Constitucional da Università degli Studi di Siena, Itália.
} 


\section{INTRODUÇÃO}

A capacidade de pensar e de sentir intimamente, que se acredita ser característica do homem, não teria significado sem a capacidade de comunicar aos outros aquilo que se pensa e se experimenta. Do ponto de vista antropológico, o pensamento e a palavra nascem juntos e se desenvolvem um através do outro. Do ponto de vista existencial, a possibilidade de objetivar-se uma mensagem, que representa ao resto do mundo as próprias emoções, experiências, reflexões, que podem deixar vestígios do Eu além da vida terrena, safisfaz uma necessidade irreprimível.

No mundo do direito, o fenômeno da comunicação entre os seres humanos está dividido em dois aspectos, que estão disciplinados de modo diverso: de um lado, a possibilidade de comunicar-se de forma discreta com os demais, em condições de privacidade (liberdade de comunicação e de correspondência); de outro, a possibilidade de manifestar o próprio pensamento a todos, de forma pública (liberdade de expressão ou de manifestação do pensamento). A primeira refere-se ao pensamento que se exaure nas relações pessoais dos indivíduos, ao passo que a segunda diz respeito ao pensamento direcionado a interagir com o resto da coletividade, vindo assim a representar um direito que, atribuído ao indivíduo para satisfação de suas necessidades individuais, pressupõe ao mesmo tempo a relação dele com os outros sujeitos do ordenamento.

A liberdade de manifestação do pensamento consiste na junção entre as liberdades que protegem a esfera íntima do indivíduo (liberdade da pessoa, de domicílio, de correspondência) e as liberdades coletivas, que tutelam diretamente a sua ação na esfera social (liberdade de reunião e de associação). Assim como as primeiras, as liberdades coletivas reclamam uma tutela absoluta. Porém, diante disso, abre-se um conflito imediato com a necessidade de conservação da ordem social (conflito esse que pode ser considerado benéfico ou destrutivo, de acordo com o tempo e o regime, v. par. 3).

Pode-se dizer que isso é fruto de evolução histórica, na qual primeiramente foi reconhecida a liberdade de consciência, compreendida como liberdade de professar o próprio credo de forma privada, em âmbito familiar e entre os amigos, sem direito ao culto público e ao proselitismo; e somente mais tarde foi reconhecida a liberdade de manifestar publicamente as próprias convicções religiosas e o próprio pensamento em geral. Diante dessa afirmação, foi, de fato, necessário superar a assertiva de que os poderes temporal e espiritual sempre avançaram em conformidade com as ideologias, paixões e inclinações coletivas. Símbolo dessa alegação é a figura "do louco da aldeia" ou do bobo da Corte, que nas sociedades fortemente estruturadas de um tempo, eram os únicos a poder dizer publicamente aquilo que pensavam. Como na fábula onde somente o menino, que, se tratando de pessoa imatura e irresponsável, tinha a coragem de gritar: o rei está nu' ${ }^{3}$.

\footnotetext{
${ }^{3}$ Está neste caso o autor a se referir ao conto "A Roupa Nova do Rei", em que um esperto alfaiate teria convencido o rei de que Ihe faria uma roupa com um tecido mágico, os quais somente os
} 
A história da liberdade de manifestação do pensamento passa, portanto, da objeção à proibição de expor as queixas e as críticas aos atos dos Poderes Públicos (MILTON) à reivindicação da livre investigação da verdade nos confrontos das ideologias dominantes, coincidindo integralmente com os processos que conduziram à emancipação do pensamento religioso, filosófico e político, da arte e da ciência, do Princípio da Autoridade. Figuras como Marinho Lutero e Galileu Galilei simbolizam esses processos, que, através de uma progressiva neutralização e secularização do poder político estatal, resultaram em um pluralismo característico das modernas sociedades liberal-democráticas.

Isso se baseia na afirmação de que não existe uma única verdade, que deva ser mantida fechada, sob custódia, bem como que a convivência entre os homens livres e iguais somente se pode advir do livre confronto entre as opiniões de cada um deles. A liberdade de expressão vem como pedra angular da democracia, compreendida como sistema aberto e transparente de comunicação entre a sociedade civil e o Estado: foi-se a época da repressão do pensamento individual e abrem-se os questionamentos sobre os procedimentos e as regras necessárias a fim de permitir a circulação e o conflito de ideias.

\section{EVOLUÇÃO DOS MEIOS E DO PÚBLICO AO QUAL É DESTINADA A MANIFESTAÇÃO DO PENSAMENTO}

Para compreender as problemáticas constitucionais relativas à liberdade de manifestação do pensamento, é indispensável recordar que o significado dessa liberdade é condicionado, de forma taxativa, não só ao conteúdo da mensagem (conformista ou conflitual em relação à ordem constituída, visando a estimular a reflexão, ou, em vez disso, incitar a ação), não só à forma (grotesca e vulgar, em vez de rebuscada ou compreensível somente a poucos mais experimentados), mas também do meio através do qual a mesma se exerce. Considerando cada meio individualizado, percebe-se que há variação na eficácia da mensagem, seja pela quantidade daqueles que podem exprimir o pensamento, seja pela extensão do público a que o mesmo pensamento é dirigido.

Por exemplo, a palavra é a declaração de (quase) tudo. Porém é um meio que, por si só, é inidôneo para atingir uma coletividade inteira: a menos que não se tenha referência a um grupo restrito, o qual podia consistir na "polis" grega reunida na ágora.

Por sua vez, a expressão do pensamento por escrito foi, por muitíssimo tempo, privilégio de poucos, destinada a uma difusão limitadíssima, enquanto a imprensa não tornou possível a multiplicação dos exemplares. Com a evolução técnica e com a crescente alfabetização, a palavra escrita obteve um impacto maior sobre o público, mas se manteve disponível apenas para as classes instruídas e abastadas.

sábios tinham condições de ver. Constrangido pelo fato de não enxergar a roupa, não admitindo não deter a condição de sábio, o rei saiu à rua nu. $\mathrm{E}$, neste caso, somente um ingênuo menino teria gritado que o rei estaria nu. (N.T.) 
O cenário mudou radicalmente na nossa época, que é completamente dominada pelos meios de comunicação de massa, bem como pelo conúbio entre o desenvolvimento do mercado e a difusão das informações. O rádio, o cinema e a televisão são meios a disposição de poucos, dado ao seu custo, mas já são capazes de atingir todo o globo e de serem facilmente compreendidos por qualquer pessoa.

No que diz respeito à imprensa, a radiofusão através do espaço encontra, além disso, os limites decorrentes da reduzida disponibilidade do meio, que não pode veicular um número indefinido de transmissões. Estes limites estão hoje em via de serem superados, graças à aplicação da tecnologia digital, que permite a multiplicação do número de programas transmissíveis sobre as mesmas frequências terrestres e, também, graças à difusão por cabo e por satélite como meios alternativos de transmissão.

Os desenvolvimentos da telemática (formada pela junção das palavras: telecomunicação informática) permitem também utilizar as redes globais, como a Internet, para difundir, em todos os lugares, textos escritos, músicas, filmes e programas televisivos, oferecendo ainda aos destinatários a possibilidade de interagir com a mensagem através do próprio processador eletrônico.

Acredita-se que a integração ou a convergência entre os vários meios (até agora destinados a utilizações várias), na única categoria da comunicação eletrônica interativa, terminará por transformar radicalmente o sistema de informação. Em particular, à televisão aberta, utilizada passiva e indiscriminadamente por todos, deveria substituir uma série de "serviços" e "produtos", criados para diversos tipos de público e escolhidos livremente pelos usuários (infra, par. 7.12).

Compreende-se, portanto, como as problemáticas constitucionais relativas à liberdade de manifestação de pensamento, nascidas no século passado e relacionadas principalmente à difusão da imprensa, estão hoje acompanhadas de novas problemáticas, conexas aos fenômenos de comunicação de massa e, ainda mais recentemente, à comunicação de multimídia.

\section{PROBLEMÁTICAS CLÁSSICAS DA LIBERDADE DE PENSAMENTO}

Nos ordenamentos, antigos e recentes, baseados no Princípio da Autoridade, a manifestação do pensamento individual sempre representou um perigo, o qual se buscou enfrentar não somente com a adoção indiscriminada da censura, mas também com a ameaça de sanções penais. Característica destes regimes é, de fato, a tipificação dos crimes de opinião, visando a incriminar as manifestações do pensamento que contestam os princípios fundamentais do regime e que incitam a desobediência às leis e às autoridades públicas.

Como exemplo, lembramos alguns dos crimes previstos no Código Rocco (dos quais tornaremos a falar em seguida, par. 8): instigação ao ódio entre as classes sociais, propaganda de práticas contraceptivas, apologia ao crime, incitamento ao desprezo pelas instituições... 
Nestes sistemas é estabelecido, portanto, o respeito pela "ordem pública", não só no sentido material (como a proibição de atos que prejudicam a paz), mas também no sentido ideal (proibição de circulação de ideias dissidentes).

Tal respeito vem reforçado positivamente com o desenvolvimento de uma informação (também através da arte, da ciência) acerca do regime. Isso, no nosso século, através do uso dos meios de comunicação de massa, transformou-se em um instrumento de manipulação totalitária da opinião pública.

Nos ordenamentos baseados no princípio da liberdade, ocorre o inverso: a interação entre o indivíduo, como ser pensante, e a coletividade com a qual se relaciona é valorizada e erigida como fundamento do sistema político.

$\mathrm{Na}$ ideologia do Estado Liberal, isso significava que não só a liberdade de expressão (juntamente com todas as outras liberdades do indivíduo) representa a legitimação do poder do Estado, mas que essa igualmente condiciona e influencia o correto funcionamento do regime político, compreendido como regime fundado na soberania da "opinião pública". Neste modelo - que corresponde aos regimes representativos oligárquicos do século passado a relação entre Estado e cidadãos se baseia, de um lado, na investidura eleitoral e, de outro, sobre o controle que a imprensa livre exerce sobre as decisões parlamentares.

A imprensa surge aqui como "órgão" da sociedade, como pressuposto da perfeita coincidência entre aqueles que exercitam a liberdade de manifestação do pensamento (potencialmente, todos os cidadãos com direito a voto) (BALDASSARRE) e aqueles que são destinatários dessa liberdade, enquanto elite intelectual e competente. Deste modo, a liberdade de expressão satisfaz automaticamente o interesse da coletividade, através da circulação das ideias e da informação, efetivando ao mesmo tempo o valor individual e social em que se assenta a própria liberdade.

Isto explica como, nessa época, a única problemática constitucional é resguardar a proteção da liberdade de pensamento da ingerência dos poderes públicos, ou a precisa identificação dos limites das medidas restritivas a que esta possa estar sujeita.

Nesta proteção, confrontam-se duas posições, que não divergem tanto nos pressupostos filosóficos quanto na avaliação da capacidade humana de raciocinar (DI GIOVINE).

A postura do otimismo liberal é própria de quem entende danoso negar qualquer tipo de manifestação do pensamento, independentemente da forma e do conteúdo, sob o fundamento que, no confronto entre as boas e as más ideias, as primeiras são destinadas a prevalecer e que, portanto, graças à necessidade de buscar sempre novos argumentos a favor delas, terminam por se enraizar definitivamente na consciência coletiva (MILL). À semelhança do livre mercado, que se acredita assegurar a maior utilidade econômica para a 
coletividade, "o livre mercado das ideias" asseguraria, portanto, a prevalência das convicções políticas mais "justas".

A ideia oriunda desse pensamento liberal radical é vista ainda hoje na sentença (proferida em 21 de junho de 1989 na causa Texas contra Johnson, publicada em Giur.cost, 1990, 1725 ss.), através da qual a Corte Suprema dos Estados Unidos entendeu que o ato de queimar a bandeira americana - no âmbito de uma manifestação de protesto contra a política governamental - não tipifica o crime de vilipêndio, por ser considerado expressão da liberdade de pensamento, protegida pela I Emenda. O raciocínio, logicamente irrepreensível, que fundamentou a decisão, é que se a adesão ao sistema político se baseia, nos Estados Unidos, no reconhecimento da liberdade, o exercício dessa mesma liberdade não pode ser usado para enfraquecê-la, devendo, pelo contrário, reforçá-la.

Também a manifestação das ideias racistas - até que não se caracterize em comportamentos violentos - é trazida pela praxe americana à tutela da I Emenda. Salienta-se, neste contexto, como a oitiva de mensagens evidentemente errôneas (e fonte de legítima indignação) é capaz de educar o raciocínio e a tolerância, e, portanto, de consolidar as bases do sistema liberal (BOLLINGER).

Como se percebeu, esta postura se justifica em um contexto social homogêneo e pacífico; parece, no entanto, de difícil pragmaticidade nos momentos de crise, como a própria experiência americana demonstra. O mesmo ocorre nos ordenamentos onde os valores de liberdade e de tolerância não são efetivamente partilhados (NANIA).

Outra posição, liberal moderada, é representada por aqueles que consideram ser coexistenciais à liberdade de pensamento alguns limites (assim considerados limites lógicos), sem os quais essa serviria continuamente aos abusos em detrimento dos indivíduos e da coletividade. Nesta ótica, é necessário restringir a tutela constitucional unicamente ao pensamento "puro" e não ao pensamento que possa incitar à ação; ao pensamento que estimula a reflexão, mas não aquele que estimula as emoções ou os instintos irracionais; ao pensamento que adota um modo urbano e cortês e não grosseiro e vulgar; ao pensamento claro e direto, não aquele traiçoeiro e insidioso; o pensamento que, afinal, não ponha em xeque a própria liberdade de pensamento.

A este propósito, releva-se o denominado paradoxo da tolerância, na base do qual se depreende que praticar a tolerância nos limites daqueles que contestam um valor, conduz cedo ou tarde à prevalência desses últimos, e, portanto, à perda da liberdade de todos.

À base deste modo de ver, há, portanto, a ideia pessimista, que nem sempre a verdade triunfa e que o público deva ser protegido daquelas manifestações que, por seu conteúdo ou pela modalidade expressiva, resultam excessivas e perigosas. 
Tal ideia, contudo, associa-se frequentemente à convicção que os chamados limites lógicos devam ser entendidos de forma mais flexível, com relação às formas de pensamento privilegiadas, sendo consideradas portadoras de uma função benéfica para a coletividade. Entre elas, a arte e a ciência de um lado; a propaganda política e a informação, de outro.

Em particular, a preferred position, outorgada ao jornalista em comparação com o cidadão comum, reforça o tradicional papel da imprensa como expressão de liberdade e instrumento para realização do interesse coletivo à circulação das notícias e das ideias além, definitivamente, do bom funcionamento do sistema político. Privilégio igual foi também estabelecido pelo ordenamento jurídico norte-americano, onde a imprensa conquistou uma efetiva independência nos limites do poder político, merecendo a definição de "quarto poder" do Estado; mas isso não é, facilmente, passível de generalização, mormente onde não haja condições comparáveis de autonomia e de pluralismo das informações.

\section{PROBLEMÁTICAS CONTEMPORÂNEAS DA LIBERDADE DE PENSAMENTO}

\subsection{A Proteção dos Valores da Liberdade e Democracia}

Em muitos ordenamentos contemporâneos, o paradigma clássico da liberdade de pensamento, baseado em uma harmoniosa conciliação entre valor individual e valor social, vem sendo questionado sobre vários aspectos, dando origem a novas e particularmente complexas problemáticas constitucionais.

A primeira problemática diz respeito à relação entre a liberdade de pensamento e a conservação do ordenamento democrático. A visão liberal, na qual há uma solução de continuidade lógica e imediata entre a liberdade individual e sua função social, resulta insatisfatória sobretudo nos países onde, depois da experiência traumática dos regimes autoritários, houve a necessidade de se reestruturar, não só através da base formal do sufrágio universal, mas através do real envolvimento de todos os cidadãos no novo sistema, partilhando os valores de liberdade e de democracia.

Esta necessidade se traduz na ideia de que o ordenamento constitucional democrático, se não almeja aumentar o risco de involuções autoritárias, deve manter-se legitimado a proteger os seus valores fundamentais nos confrontos do pensamento antiliberal e antidemocrático.

No regime constitucional da Alemanha Ocidental, esta ideia se exprime na fórmula da streitbare Demokratie e se concretiza do artigo 18 da $\mathrm{GG}^{4}$, o qual estabelece que aquele "que abusa da liberdade de manifestação do pensamento, de imprensa, de ensino, de reunião, de associação, de privacidade na correspondência, do direito de propriedade ou do direto de asilo com o intuito de combater a ordem liberal-democrática, perde a titularidade desses direitos fundamentais".

\footnotetext{
${ }^{4}$ Lei Fundamental Alemã (nota do tradutor).
} 
Tal disposição prevê, portanto, um controle sobre o conteúdo do pensamento expresso em função da manutenção do regime político, ou ainda a instauração de uma "ordem pública ideal", protegida contra as manifestações de dissenso.

Trata-se, evidentemente, de uma referência ao paradoxo da tolerância, que é composto de conteúdos específicos (os princípios do regime liberaldemocrático, assim como interpretados e aplicados em diversas etapas pelas instituições estatais) e que, portanto, implica uma subordinação do pensamento individual a uma finalidade coletiva, em uma total ruptura com a tradição liberal.

Como já foi referido (CRISAFULLI), tal escolha constitucional é comparável ao princípio adotado por aqueles regimes que reconheciam a liberdade de pensamento "em função da consolidação da ordem socialista". Pode-se, seguramente, entender que exista uma diferença, mais quantitativa que qualitativa, entre a sujeição da liberdade de pensamento aos princípios do regime e a sua explícita funcionalização à concretização de tais princípios.

\subsection{A Garantia da "liberdade igual"}

A segunda problemática nasce da garantia assim chamada "liberdade igual" ou liberdade positiva (BÖCKENFÖRDE), que caracteriza alguns ordenamentos europeus do pós-guerra.

Se, no passado, o reconhecimento das liberdades assegurava o gozo das mesmas somente àqueles que dispunham de dinheiro, de tempo e de cultura para usufruí-las, o Estado Constitucional democrático se propõe, pelo contrário, a estender a todos os cidadãos a concreta possibilidade de tal proveito. Somente em virtude de tal extensão, de fato, pode-se tentar recriar a concepção de efetiva coincidência entre titulares e destinatários da liberdade de pensamento, ou de coincidência entre o valor individual e o valor social da liberdade, que estavam presentes no modelo liberal.

A livre circulação de ideias e de notícias, da qual se alimentava aquele modelo, é de suma importância nos sistemas baseados na soberania popular e na igualdade dos direitos políticos, que pressupõem o conhecimento e a consciência de questões sobre as quais o cidadão é chamado a decidir.

Isso comporta, antes de mais nada, uma série de intervenções diretas a fim de promover a difusão da instrução e da cultura entre os cidadãos, como condição indispensável para o desenvolvimento da liberdade de pensamento de cada um. A fim de efetuar isso, seria preciso também garantir a todos a disponibilidade dos meios de difusão: sem os quais aos "pobres coitados", como diz Crisafulli, "nada resta que não a liberdade de escrever 'viva' e 'abaixo' sobre o muro"

\footnotetext{
${ }^{5}$ A expressão usada por Crisafulli, referida pelo autor no texto, é "non rimane altro che la libertà di scrivere viva e abasso sul muro". Tal expressão, especificamente no que tange aos termos "viva e abasso" claramente faz alusão às interjeições "viva" e "abaixo" como meios de exprimir
} 
Tal condição mantém-se, todavia, impossível de ser atingida, pelo fato de outorgar, inevitavelmente, ao poder público, a escolha dos indivíduos habilitados a usar os meios e, portanto, também das ideias e das notícias destinadas a circular. Em outras palavras, a estatização dos meios de difusão - ainda que esteja a serviço da liberdade de pensamento - é considerada um remédio pior que o mal, pois não garantiria ou a ultimação do paradigma liberal. Seria, pelo contrário, como que ignorá-lo completamente.

A este respeito, cita-se como exemplo a experiência dos regimes socialistas, que puseram alguns meios de comunicação à disposição dos trabalhadores, a fim de que (já citado acima, par. 4.1) a manifestação do pensamento se desse com a finalidade de consolidar os princípios do regime. E disso se depreende que a tutela da liberdade de pensamento está indissoluvelmente fundada na manutenção do regime de apropriação privada dos meios de difusão e da liberdade de iniciativa econômica.

Com base nessas premissas, a garantia da "liberdade igual" está inserida na ideia do pluralismo de informações, compreendida como garantia do mais amplo acesso aos meios de difusão, levando em consideração as condições econômicas e tecnológicas que a caracterizam. Não se trata, ao menos neste aspecto perfunctório, de uma meta atingível. A realidade moderna da massmedia demonstra que estes são muito mais fortes, muito mais caros e tendem a concentrar-se irremediavelmente nas mãos de poucos.

A problemática constitucional concentra-se, portanto, nos meios e instrumentos através dos quais o Estado pode recorrer para limitar ou integrar a iniciativa econômica privada, a garantia do pluralismo informativo. A respeito disso, os ordenamentos jurídicos contemporâneos impuseram diversas formas de intervenção, que levam em consideração as diferentes condições econômicas, tecnológicas e constitucionais.

A solução restritiva, que observa o princípio da não-intervenção do Estado em matéria de liberdades, consiste na introdução de uma severa disciplina antitruste, visando a evitar que as empresas mais fortes criem condições de inacessibilidade ao mercado de informações. Essa solução pressupõe, por outro lado, a concreta existência de um grande número de empresas capazes de competir entre si. Enquanto esta condição não se realiza, admite-se que o Estado possa intervir, em primeira mão, para alargar o panorama das opiniões e informações circulantes: seja com o financiamento em favor de iniciativas socialmente e culturalmente relevantes, seja, realmente, com a criação de empresas editoriais, de radiofusão ou televisivas por parte do próprio Poder Público. No primeiro caso, a intervenção é obviamente condicionada à observância das condições de imparcialidade e neutralidade na distribuição dos recursos (SCHLAICH); no segundo caso, o desenvolvimento de uma

exaltação e crítica. A intenção do autor foi a de referir pichações em muros, com meros elogios e críticas sem muito conteúdo. (N.T.) 
função informativa e de entretenimento por parte do Poder Público se justifica em virtude da necessidade de "corrigir" as lacunas do oligopólio privado (o qual visa à obtenção do lucro), e, portanto, se destina a veicular uma informação objetiva, a garantir a difusão das posições e ideias minoritárias e a promover a iniciativa cultural.

A solução extensiva consiste, por outro lado, em reservar exclusivamente ao Estado o uso de um determinado meio, sob o fundamento de que não existiriam, em relação ao mesmo, condições técnicas e econômicas para o desenvolvimento de uma concorrência satisfatória entre os entes privados. Esta escolha, que foi a seguida, no passado, pela radiotelevisão (tanto na Itália como no resto da Europa), está sujeita a duas condições: em primeiro lugar, a manutenção da liberdade de iniciativa econômica para os outros meios de comunicação (em particular, a imprensa); em segundo lugar, o empenho do Estado a garantir o mais amplo acesso ao meio por parte da coletividade, além de promover a abertura a todas as tendências culturais e ideais presentes na sociedade.

\subsection{Massmedia e Funcionamento da Democracia}

A terceira problemática é posta tendo em vista à mudança qualitativa da informação, relacionada com o surgimento da nova massmedia.

Esta se caracteriza pela especial capacidade de difusão e pela penetrante eficácia a mensagem, que tem como destinatário um público potencialmente ilimitado, através do uso de sons e imagens sugestivas. O "produto" televisivo, do ponto-de-vista de quem o cria, tende a ser o mais simples e imediato possível; do ponto-de-vista de quem o recebe, não requer um empenho e uma participação particular. No caso das mensagens subliminares, essas têm como alvo o inconsciente dos espectadores e se subtrai a qualquer forma de controle por parte dos mesmos.

Como se diz o célebre slogan, o meio é a mensagem: como o meio da imprensa se presta a uma fruição ativa e crítica, o meio televisivo se presta, por natureza, a uma fruição passiva e acrítica. O desenvolvimento da "função social", característica da imprensa no modelo liberal, torna-se, dessa forma, ainda mais problemático, sob dois perfis diversos.

Em primeiro lugar, a massmedia surge como instrumento principal para o desenvolvimento do mercado, mais que para a difusão das ideias. À diferença da imprensa de opinião de um tempo, deixada à iniciativa do editor, as grandes empresas de massmedia não nascem visando à divulgação de um projeto político cultural, nem mesmo para obter a maior publicidade comercial possível. Determinam-na vários fenômenos, entre eles a confusão entre informação e entretenimento, o empobrecimento das iniciativas culturais, a forte difusão de estilos de vida, estimulando exclusivamente o consumo.

Em segundo lugar, a massmedia submete também à sua lógica a informação política, que é vital para o correto funcionamento da democracia. 
Isso se registra, por um lado, com o acesso à propaganda televisiva pelos únicos partidos e candidatos que podem arcar com os custos (Money is speech); do outro, com o recurso à pesquisa e referendos através da televisão, nos quais se estimula o público a votar em alternativas predeterminadas, alimentando o sonho da denominada teledemocracia (RODOTÀ).

Essas e outras constatações deram lugar a uma vasta literatura de crítica à televisão (POPPER, SARTORI), colocando em foco a necessidade de limitar o caráter invasivo deste meio, seja para proteger o desenvolvimento da personalidade de cada um, seja para proteger a formação de opinião pública democrática.

Trata-se de um objetivo diverso e ulterior, relativo ao pluralismo informativo. Isso advém da convicção que o pluralismo (assim como o formulado acima, par. 4.2), não obstante permitir ao público o confronto entre ideias e notícias diversas, não oferece um panorama verdadeiramente completo dos problemas e das opiniões circulantes, além de não protegê-lo do uso distorcido do meio televisivo com intuito lucrativo.

Mesmo sendo muito contestado por aqueles que o entendem como liberticida e paternalista, este objetivo adentrou em diversos ordenamentos jurídicos. Também neste caso, foram arroladas várias hipóteses de aplicação que podem rechaçar profundamente o paradigma liberal, enquanto agem sobre o conteúdo da mensagem televisiva.

Em primeiro lugar, estão a disciplina do tempo e da forma de publicidade, com particular atenção à proibição de mensagens subliminares, e a tutela da liberdade e/ou da saúde dos indivíduos.

Em segundo lugar, as proibições ou limitações de horário para as transmissões que possam ofender a sensibilidade dos menores ou dos bons costumes.

Em terceiro lugar, a aplicação do pluralismo em seu sentido qualitativo, em relação aos mercados fechados. Enquanto o acesso de um meio seja intrinsecamente limitado pela escassez dos recursos disponíveis, o Estado deveria selecionar as empresas aspirantes sobre uma base de precisos critérios de merecimento, tendo em vista a criação de panorama efetivamente diversificado de vozes e opiniões.

Em quarto lugar, a recondução das empresas radiotelevisivas à categoria dos serviços públicos, ao menos no que se refere à função informativa, a fim de submetê-las a critérios de objetividade e completude análogos àqueles impostos ao serviço público estatal.

Em quinto lugar, a imposição, a essas empresas, de limites ainda mais restritos, em relação a matérias decisivas para a correta formação da opinião pública: em particular, a obrigação de observar, durante as campanhas eleitorais, o respeito à imparcialidade na informação e em condições de igualdade na venda dos espaços de propaganda. 


\section{A CONSTITUIÇÃO ITALIANA}

\subsection{O Artigo 21 no quadro dos Princípios Constitucionais}

Todas as questões há pouco referidas também são postas pela Constituição Italiana, como emerge da leitura do artigo $21^{6}$ e, ainda mais, da exegese geral da Carta.

O artigo 21 é uma previsão complexa, formada por duas partes distintas, ainda que conexas entre si: de um lado, a garantia da liberdade de manifestação do pensamento, que é reconhecida a todos, por qualquer meio, ressalvado o limite atinente aos bons costumes (primeiro e último parágrafos); de outro lado, em direta atuação desse reconhecimento, a específica e detalhada garantia à liberdade de imprensa (parágrafos segundo, terceiro, quarto e quinto).

Esta previsão possui, antes de tudo, um significado histórico, de notória polêmica relativa à experiência fascista: seja a ampla proclamação da liberdade, efetivada sem referência a limites de ordem pública, seja a particular atenção à liberdade de imprensa, considerada a peça chave para a formação de uma livre opinião pública.

No plano dos valores constitucionais, isso significa uma irrestrita adesão ao princípio liberal, que vem fortemente enfatizada e acompanhada de todas as garantias decorrentes da rigidez constitucional, superando o estreito enunciado do Estatuto Albertino ("A imprensa é livre, mas a lei reprimirá os abusos").

Diz-se que este resultado, essencialmente relevante para as liberdades individuais e também para a estabilidade do regime político, não pode ser reduzido a mero relato histórico, devido ao fato de que o silêncio que o artigo 21 deu origem a muitas problemáticas, sejam clássicas ou contemporâneas (em particular referentemente aos novos meios de comunicação de massa).

Isso não significa, de fato, que os constituintes ignoraram os desafios a serem enfrentados pela liberdade de manifestação do pensamento na realidade dos sistemas liberal-democráticos, mas sim que esses vão ser abordados à luz de todos os princípios constitucionais.

\footnotetext{
${ }^{6} \mathrm{O}$ artigo 21 da Constituição Italiana contém a seguinte redação: Todos tem direito de manifestarem livremente o seu pensamento, seja através da palavra, da escrita ou outro meio de difusão. A imprensa não pode estar sujeita à autorização ou censura. Pode-se proceder ao sequestro somente em caso de decisão motivada de autoridade judiciária em caso de crimes, para os quais a lei de imprensa expressamente o autorize, ou em caso de violação das normas que esta mesma lei prescreva para indicação dos responsáveis. Em tais casos, quando haja absoluta urgência e não seja possível a tempestiva intervenção da autoridade judiciária, o sequestro do material informativo pode ser executado por oficial da polícia judiciária, que devem, imediatamente, em tempo não superior a vinte e quatro horas, comunicar o fato ao juiz. Se isso não se convalidar nas sucessivas vinte e quatro horas da apreensão, o sequestro se entende revogado e desprovido de quaisquer efeitos. A lei pode estabelecer, com normas de caráter geral, que sejam publicados os meios de financiamento da imprensa periódica. É proibida a publicação na imprensa de espetáculos ou outras formas de manifestação contrárias aos bons costumes. A lei estalecerá meios adequados a fim de prevenir e reprimir a violação a este enunciado. (N.T.)
} 
Em outras palavras, o artigo 21 se reporta, pela sua interpretação, a toda Carta Constitucional. Tal conclusão é inegável (e ocorre também através de previsões análogas contidas em outras constituições), do momento em que (como se viu acima, parágrafo um) a liberdade de manifestação do pensamento envolve, por sua essência, não só a tutela das necessidades individuais, mas a garantia de funcionamento do sistema político como um todo.

É, portanto, tarefa do intérprete reconstruir o significado geral da liberdade de pensamento em nosso ordenamento, à luz dos princípios e das disposições que the são relevantes. Para compreender toda complexidade de tal tarefa, basta recordar brevemente quais e quantas são as previsões constitucionais envolvidas no caso e frequentemente em conflito entre si.

Em se tratando de limites à liberdade de pensamento, releva-se, antes de tudo, a garantia de outros direitos invioláveis (artigo $2^{\circ}, 13 \mathrm{ss}$.); em segundo lugar, a tutela das leis e das instituições republicanas (a fidelidade à República e a defesa da Pátria, ex. art. 54 e 52 da Constituição); em terceiro lugar, um (possível) limite de ordem pública, em consequência da proibição de reconstituição do partido fascista, ex. art. XII das Disposições Constitucionais Transitórias).

Em se tratando da "liberdade igual", releva-se a supranorma do artigo $3^{\circ}$, parágrafo segundo, que visa a assegurar o efetivo gozo dos direitos e a participação de todos na vida do país, os quais, no nosso estudo, não se podem deixar de relacionar os artigos $9^{\circ}$, sobre a promoção da cultura e da pesquisa científica, e 34, sobre o direito ao estudo.

Referentemente à liberdade de iniciativa econômica, devem-se citar os artigos 41, que prevê os limites da segurança, liberdade e dignidade humanas, bem como limite da denominada utilidade social, além do artigo 43, que estabelece a reserva ao Estado das atividades que se referem aos serviços públicos essenciais e que tenham caráter de proeminente interesse geral.

Quanto ao valor da livre circulação das ideias como valor social ou coletivo conexo à liberdade de pensamento, põem-se em relevo os mesmos princípios sobre os quais se baseia a forma de Estado, que são, ao mesmo tempo, a garantia da soberania do povo e o reconhecimento dos direitos invioláveis (artigos $1^{\circ}$ e $2^{\circ}$ ); na verdade, ambos demandam a existência de escolhas livres e pressupõem, portanto, uma adequada informação da opinião pública e de qualquer cidadão.

Estes princípios, característicos de todos os sistemas liberal-democráticos, são também qualificados, em nosso ordenamento, pela específica finalidade de desenvolvimento da personalidade de cada indivíduo, que se nutre, de um lado, de um sistema pluralista (ainda artigo $2^{\circ}$ ) e de outro, do anseio do efetivo gozo dos direitos (artigo $3^{\circ}$, terceiro parágrafo).

Por fim, pode-se dizer que a Constituição disponibiliza todos os seus recursos para assegurar, com perfeição, a efetividade do paradigma liberal e, 
ao mesmo tempo, garante a aplicação de novos princípios, que são passíveis de estabelecer uma forma de articulação/evolução ao referido paradigma.

\subsection{A Liberdade de Imprensa}

A dialética entre velhas e novas problemáticas da liberdade de pensamento que advém do quadro constitucional se reflete diretamente na disciplina da liberdade de imprensa, a qual são dedicados os parágrafos $2^{\circ}$ ao $5^{\circ}$ do artigo 21. Desses parágrafos emergem a retomada e o aprofundamento do paradigma liberal clássico, mas também a ciência dos problemas que podem emergir do citado paradigma.

Sob a primeira acepção, a Constituição prevê um considerável número de garantias; sob a segunda, uma forma (eventual) de controle social.

As garantias dizem respeito à natureza e às modalidades das medidas restritivas a que a imprensa pode estar sujeita e se consubstanciam em uma reserva legal absoluta e reforçada, também em uma reserva de jurisdição, afastável somente em limitadíssimas condições.

1. A reserva legal: a lei não pode prever autorizações ou censuras, ou seja, a obrigação de submeter as publicações a um controle preventivo, que tenha por fim inibir, em todo ou em parte, a difusão. Admite-se, entretanto, a apreensão do material informativo, por iniciativa da autoridade competente, mas somente nos casos em que se verificam a prática dos delitos previstos, anteriormente, na lei de imprensa, ou ainda que contenham violação a normas que estabelecem a indicação, no material impresso, do responsável pela publicação. Isso significa que a restrição da divulgação do pensamento e das notícias se justifica exclusivamente em virtude do interesse geral à repressão de crimes mais graves (crimes, salienta-se, não simples contravenções), bem como da identificação da autoria da publicidade.

2. A reserva de jurisdição: a competência para determinar a apreensão pertence, ordinariamente, não à autoridade administrativa, mas ao juiz, através de decisão motivada. Somente em se tratando de imprensa periódica (em não se tratando de livros ou anúncios), onde seja caso de absoluta necessidade e urgência, o sequestro pode ser feito, de forma provisória, pelo oficial de polícia judiciária, que deve comunicar ao juiz em 24 horas; caso isso não seja convalidado pela autoridade judiciária nas 24 horas seguintes, o sequestro se considera revogado, restando sem efeito.

A Corte Constitucional entendeu que a expressão "lei de imprensa" não deve ser compreendida como uma especial reserva de lei, considerando que a indicação dos crimes pode estar contida em qualquer outro diploma legislativo.

As leis vigentes admitem, além do sequestro ocorrido posteriormente à violação, que é estabelecido pelo juiz em sentença, alguns casos de sequestro preventivo, visando a inibir a difusão do material informativo. Essa medida (que é particularmente grave, porque frustra não só a liberdade individual de difundir a manifestação do pensamento, mas também o 
interesse na circulação das idéias e das notícias) é prevista somente para as publicações obscenas ou contrárias à decência pública (artigo $2^{\circ}$ r. Decreto Legislativo $n^{\circ} 561$, de 31 de maio de 1946) e para o material informativo que contenha apologia ao fascismo (artigo $8^{\circ}$ da Lei $n^{\circ} 645$ de 20 de junho de 1952).

A Corte Constitucional admitiu, porém, a legitimidade de providências similares ao sequestro, quando estão em jogo direitos de indivíduos que podem sofrer prejuízo em face das publicações, ainda que não seja caso de um delito. A Corte entendeu que (Sentença $n^{\circ}$ 38/1975) o juiz civil pode proibir a utilização de material que é destinado à imprensa (mas não ainda divulgado) quando houver requerimento de um indivíduo visando à tutela dos "direitos absolutos da personalidade". (abaixo, parágrafo 7.5).

Seguindo essa linha, recentemente, o legislador italiano foi instado à previsão de que o denominado "garante da privacidade" possa bloquear, através de simples sinalização, a publicação de dados pessoais ilícitos, incorretos ou prejudiciais aos envolvidos (artigos 143 e seguintes da Lei $n^{\circ}$ 196, de 30 de junho de 2003).

Considera-se que a noção de "dados pessoais" abrange qualquer tipo de informação e de imagem relativa a um sujeito, e que o garante não pode ser de algum modo uma autoridade jurisdicional (Corte de Cassação, seção I, 20 de maio de 2002, n 7341). Não se pode desconsiderar a violação ao artigo 21 da Constituição por uma forma de sequestro preventivo administrativo, já que se pode restringir a imprensa mesmo na ausência de delito e de imediata convalidação por ato do juiz.

Da comparação com a disciplina das outras liberdades fundamentais, infere-se que a liberdade de imprensa periódica goza de vasta e profunda proteção: há uma reserva de lei absoluta e reforçada, como em muitas outras liberdades - mas somente no caso em comento a Constituição vincula o futuro legislador a conteúdos bem determinados (violação das normas sobre responsabilidade) ou determináveis, com limitada discricionariedade (delitos previstos pela lei de imprensa); há também uma reserva de jurisdição, prevista também nas garantias estabelecidas nos artigos 13, 14 e 15, porém somente na hipótese em tela a mesma é dispensável em limitadas circunstâncias: em razão de que somente pode se dar através de oficiais de polícia judiciária (e não de autoridades administrativas em geral) e com termo definido (24 horas para a comunicação ao juiz e mais 24 para a convalidação, em vez de 48 mais 48).

Esta disciplina hipergarantista da imprensa se justifica evidentemente em virtude não só de seu valor individual, mas do papel insubstituível que a livre e criteriosa difusão das notícias desenvolve na formação da opinião pública.

Esse papel positivo ou benéfico não é assim tão ostensivo, como era no modelo liberal: a Constituição demonstra ter ciência do risco de que a imprensa, em determinados contextos econômicos, possa cair nas mãos de poucos privilegiados e venha a ser utilizada para manipular a opinião dos cidadãos. Admite-se, portanto, que a coletividade seja informada sobre quem financia 
os meios de informação, de modo a poder avaliar a objetividade das notícias fornecidas.

Trata-se de um limite em favor da transparência da informação, que não atinge, de qualquer forma, a liberdade de conteúdo. Isso é atribuído à lei e concebido em termos não imperativos, mas permissivos ("a lei pode estabelecer formas de publicidade sobre as fontes de financiamento da imprensa periódica"). No clima da constituinte, fixada na lembrança fascista, prepondera o temor que uma fórmula mais rigorosa possa ensejar uma pressão, ainda que indireta, do poder público sobre a imprensa.

Em seu conjunto, o artigo 21 corrobora, portanto, com máxima amplitude, e com a garantia da rigidez constitucional, o significado da manifestação do pensamento como liberdade instituída, que satisfaz uma exigência vital do indivíduo e, ao mesmo tempo, o inafastável interesse na formação da opinião pública. Admite, por outro lado, que a "função social" da informação não se dê sempre de forma automática, mas possa precisar de intervenções públicas que as estimulem.

\section{A ATUAÇÃO DA CONSTITUIÇÃO}

\subsection{A Dialética entre o Legislador e o Juiz Constitucional}

Segundo o princípio da reserva absoluta, referente às liberdades fundamentais, compete ao legislador transformar os princípios dedutíveis do texto constitucional em regras obrigatórias para o exercício da liberdade de pensamento. Estes encontram-se diante de delicadíssimas escolhas: seja com relação à previsão dos limites gerais da liberdade, seja com relação à disciplina da imprensa, na parte não contemplada na Constituição, seja com referência ao estatuto dos meios diversos da imprensa, que a Constituição ignora.

Tais dificuldades, na experiência do nosso ordenamento jurídico, revelam-se quase insuperáveis. O Parlamento permaneceu inerte, diante da urgente necessidade de eliminar a herança fascista, que permeou o sistema de normas liberticidas, e efetuou, com grande esforço, a modernização da disciplina das empresas editoriais e de radiotelevisão. A este respeito, a pressão dos agentes econômicos foi tão forte de forma a causar agitação em nosso sistema político, causando seríssimos conflitos e inclusive crises de governo.

Em verdade, muito disso que ora é exposto é fruto de sentenças da Corte Constitucional; assim como, no passado, a Corte foi instada a "purificar", ao menos em parte, o ordenamento das normas fascistas.

A atuação da Constituição em matéria de liberdade de manifestação do pensamento não foi linear: mais que em outros casos, essa foi marcada como contraponto entre sentenças e leis e, nos últimos tempos, o contraponto entre regulamento comunitário e regulamento interno, sempre colidentes entre si.

Recorda-se que apenas recentemente, com o Decreto Legislativo $n^{\circ} 507$, de 30 de dezembro de 1999, o legislador tomou medidas para revogar alguns 
dos mais polêmicos crimes de opinião previstos no Código Penal (por exemplo, o ultraje a servidor público ${ }^{7}$ ) e a transformar outros (a blasfêmia ${ }^{8}$ ) em ilícitos administrativos.

Por longo tempo, não houve a introdução de uma disciplina que, com base nas especiais garantias destinadas à tutela da liberdade de imprensa, tutelasse adequadamente os direitos que essa é capaz de afrontar (como a honra, a privacidade e a sensibilidade dos menores). As poucas disposições da lei sobre a imprensa (Lei $n^{\circ} 47$ de 8 de fevereiro de 1949), adotada pela própria Assembléia Constituinte, atenderam à iniciativa comunitária, em matéria de tratamento dos dados pessoais, por ser integradas à Lei $n^{\circ} 675$, de 31 de dezembro de 1996 (ora entendida com as modificações do já citado Decreto Legislativo $n^{\circ}$ 196/2003) e do código deontológico da atividade jornalística que a mesma previu.

A Lei $n^{\circ} 416$, de 5 de agosto de 1981 (sobre a reforma da atividade editorial), realizou, naquele período, um esforço inovador, estabelecendo normas relativas à tutela da transparência (em regulamentação do parágrafo quinto do artigo 21) e normas visando a fixar limites à concentração dos periódicos. Essas últimas normas foram reiteradamente modificadas e atenuadas, a ponto de induzir a Corte Constitucional a estabelecer, pela primeira vez, um limite à criação de leis interpretativas.

Com a Sentença no 155/1990 (relativa ao caso Gemina-Rizzoli), a Corte declarou a inconstitucionalidade, por entendê-las excessivas, das disposições que, com eficácia retroativa, modificaram a noção de controle e de coligação entre empresas editoriais e elevaram ao limite máximo admissível a concentração no setor editorial.

Em matéria de cinema, a Lei $\mathrm{n}^{\circ}$ 161, de 21 de abril de 1962, regulamentando o último parágrafo do artigo 21 (que prevê medidas preventivas, além de outras repressivas, em relação às apresentações lesivas aos bons costumes), estabeleceu a obrigação de uma autorização, liberando a apresentação mediante a apresentação de um parecer de uma comissão formada por representantes da sociedade e das empresas cinematográficas.

A Lei $n^{\circ} 293$, de 30 de maio de 1995 estendeu este regime, ainda que de forma voluntária, aos filmes produzidos pela televisão. Frise-se que em relação às apresentações teatrais, essa forma de censura foi abolida pelo Decreto Legislativo $n^{\circ} 3$, de 8 de janeiro de 1998.

\footnotetext{
${ }^{7}$ Quando a autora menciona o delito de ultraje a servidor público, refere-se ele ao artigo 341 do Código Penal Italiano, que estabelece o crime de oltraggio a pubblico ufficiale, cujo tipo consiste em ofender a honra ou prestígio de um servidor público, na sua presença e em razão do exercício de suas funções. (N.T.)

${ }^{8}$ Da mesma forma, quando exara a figura de blasfêmia (bestemmia), está a autora a se referir à contravenção prevista no artigo 724 do Código Penal Italiano, cujo tipo é blasfemar, com palavras ultrajantes, contra a Divindade, símbolos ou pessoas cultuadas pela religião oficial do Estado. (N.T.)
} 
Em matéria de radiotelevisão (vide parágrafos abaixo, 7.8 e 7.12), o Parlamento republicano primeiramente ratificou o monopólio estatal estabelecido pelo regime fascista, concedendo o serviço à R.A.I, empresa privada em regime público. Após a Sentença-lei no 225/1974 da Corte Constitucional, deu-se a reforma, que introduziu novos princípios na gestão do serviço público. (Lei $n^{\circ} 103$, de 14 de abril de 1975).

Logo após, a mesma Corte declarou a inconstitucionalidade do monopólio da transmissão via espaço em âmbito local (Sentença no 202/1976), estabelecendo a instituição de um regime de outorga de autorização, com o intuito de "harmonizar a iniciativa privada com o proeminente interesse geral à livre circulação das idéias". O legislador não adotou esse entendimento, permitindo uma total "liberdade de antena", graças a que algumas empresas privadas começaram a transmissão não só a nível local, mas também a nível nacional.

Logo após alguns provimentos judiciais que impediam a transmissão em escala nacional, o legislador estabeleceu uma disciplina que autorizava tais transmissões a posteriori, ressalvando situações já estabelecidas (Decreto-lei $n^{\circ} 807$, de 6 de dezembro de 1984, convertido na Lei $n^{\circ} 10$, de 4 de fevereiro de 1985).

Depois de muitas admoestações advindas do conteúdo da Carta Constitucional, que previa a adoção de uma disciplina antitruste, foi adotada a denominada "Lei Mammì" (Lei no 223 de 6 de agosto de 1990), que instaurava um sistema radiotelevisivo misto (ou melhor, o reconhecia), introduzindo alguns limites à concentração das emissoras. Tais limites foram considerados ilegítimos, porque seriam insuficientes a garantir o pluralismo informativo (abaixo, parágrafo 7.8), pela Sentença $n^{\circ} 420 / 1994$ da Corte Constitucional, e foram, diante disso, modificados pela Lei $n^{\circ} 249$, de 31 de julho de 1997 (denominada lei "Meccanico"), a qual, porém, prorrogou o status quo na espera de um consequente desenvolvimento da televisão via cabo ou via satélite, de forma a não causar danos além da medida às emissoras que deveriam abandonar as frequências terrestres.

A prorrogação foi declarada inconstitucional com a Sentença $n^{\circ} 466 / 2002$, pelo fato de remeter a um momento futuro e incerto (dada à lentidão com a qual se desenvolve o mercado de televisão a cabo e via satélite) a dissolução das concentrações radiotelevisivas ilegais.

A decisão foi tomada depois que o Chefe de Estado, com solicitação remetida aos parlamentares em 23 de julho de 2002, fez lembrar a contínua carência de pluralismo na informação, tanto mais grave em um sistema baseado na alternância (e, portanto, sujeito à visibilidade pela oposição).

A Corte Constitucional estabeleceu, em 31 de dezembro de 2003, o termo final para a terceirização da rede privada via cabo ou satélite) - e para a renúncia da rede pública terceirizada ao financiamento publicitário. 
O legislador decidiu, a este ponto, a estimular o aumento, a curto prazo, do número de programas transmissíveis via espaço (estimulando a implementação da técnica digital terrestre: abaixo, 7.12), e de, ao mesmo tempo, ampliar a base de cálculo o total dos recursos adquiridos pelas empresas (o denominado sistema integrado de comunicações): duas medidas que consistem, na prática, em inserir as atuais posições dominantes nos limites percentuais previstos pela lei.

O Chefe de Estado considerou esta disciplina como inaceitável, à luz da jurisprudência constitucional e, diante disso, remeteu aos parlamentares a denominada "Lei Gasparri", a qual foi aprovada in extremis em dezembro de 2003. A remessa presidencial censurava tanto a ulterior prorrogação do status quo, destinada a permitir uma adequada difusão da via digital terrestre entre o público, tanto a configuração do denominado S. i. c., ampla demais para impedir a formação de posições dominantes e o desvio de recursos publicitários em prejuízo da imprensa.

O Parlamento introduziu, a esse respeito, algumas modificações (que o Chefe de Estado não poderia, posteriormente, censurar, por exemplo o artigo 74 da Constituição) e ratificou a matéria em exame, a qual se tornou lei, consubstanciada na Lei $n^{\circ}$ 112, de 3 de março de 2004. Com base nessa lei, o Governo depois editou o Decreto Legislativo n 177, intitulado "Texto Único da Radiotelevisão" (abaixo, 7.12).

Muito controversa foi também a reforma da RAI, que depois da abolição do monopólio, está em busca de uma genuína vocação de serviço público. A fim de colocar limites na ingerência dos partidos na vida das empresas, foi editada a Lei no 206, de 25 de junho de 1993, a qual instituiu um Conselho de Administração, composto de cinco "sábios", nomeados mediante consulta dos chefes das duas casas (em vez do Governo ou da Comissão Parlamentar de Vigilância), atribuindo-lhe o encargo de fiscalizar, de forma imparcial, o cumprimento das tarefas pelo Poder Público. A independência e a mesma funcionalidade deste órgão, por outro lado, entram em crise com a introdução do sistema majoritário, estabelecido por ambos os presidentes das casas, visando à designação de uma maioria, além de condicionar a escolha dos conselheiros à lógica de uma repartição desigual entre aqueles que venceram as eleições e aqueles que foram derrotados.

Em 1995, foi depois revogado, através de referendo popular, o princípio que prevê uma total participação pública no capital da RAI, deixando em aberto o quesito sobre a forma mais adequada de assegurar a satisfação das peculiares finalidades informativas e culturais do serviço público.

O ingresso de sócios privados deveria estimular a eficiência da empresa e talvez também assegurar um maior pluralismo no âmbito interno do serviço público. Muito discutível (também à luz da recente Sentença $n^{\circ}$ 284/2002 da Corte Constiucional) parece, por outro lado, a opção por privatizar integralmente a sociedade concessionária - segundo o que dispõe hoje a Lei Gasparri - e, portanto, de submetê-la exclusivamente ao sistema do lucro (abaixo, 7.12). 
Os fins em questão não podem ser considerados superados em virtude da perspectiva que hoje dá lugar à denominada convergência multimídia: ao menos por este momento, a multiplicação dos programas e dos serviços interativos se reverte ao público pagante, enquanto correlativamente diminui a qualidade e a variedade dos programas oferecidos "abertamente" a todos os cidadãos.

Em vista dos valores que a comunidade européia denomina "diversidade cultural e linguística" e "coesão social", e que, pela nossa Constituição, são princípios da democracia pluralístico-participativa, confirma-se, portanto, a necessidade de um serviço de informação (entretenimento), dotado de um padrão mínimo de qualidade e oferecido a todos a um preço acessível (em aplicação e desenvolvimento do conceito de "serviço universal" delineado pela diretiva comunitária que Ihe deu corpo através do Decreto Legislativo $\mathrm{n}^{\circ}$ 259, de $1^{\circ}$ de agosto de 2003, com o Código das comunicações eletrônicas.

\subsection{Princípios Compartilhados em Matéria de Liberdade de Manifestação do Pensamento Individual}

A evolução há pouco descrita determina uma ordem particularmente desencontrada da matéria, que vem reconstruída sobre uma base de elementos diversos por sua própria força e natureza; a Constituição e as leis vigentes, de um lado, as sentenças do juiz constitucional e do juiz comum, além da própria doutrina, de outro. As fontes informais do direito adquirem muito mais valor em um cenário legislativo assistemático, que necessita ser completado e racionalizado.

A dialética entre estes sujeitos produziu um acordo de fundo sobre algumas questões fundamentais, outorgando à liberdade de pensamento uma expansão que lhe era desconhecida no nosso ordenamento, tornando-a notável até mesmo em comparação com outros países reconhecidamente democráticos.

Isso ocorreu, sobretudo, graças à rejeição das teorias funcionalistas que vinham sustentadas logo após a entrada em vigor da Constituição. A este respeito, deve ser salientado que, na melhor interpretação constitucional, o termo funcionalização, em referência à liberdade de manifestação do pensamento, não é mais compreendido em seu sentido próprio, mas sim com alusão a uma exigência de ordem ideal ou moral.

Em Constantino Mortari, este modo de ver mantinha relação com uma ideologia católica, que não atribui às liberdades do indivíduo um significado absoluto, mas lhes subordina aos valores do ser humano. Tratava-se, portanto, de uma funcionalização ultrapositiva, incapaz de suscitar controles públicos sobre o conteúdo da informação. Por sua vez, Vezio Crisafulli, movido pelas citadas preocupações sobre a efetividade da liberdade de pensamento, tendia a considerar a imprensa como um "serviço público": o que não teria implicado, por outro lado, a seu juízo, a limitação da liberdade do jornalista (logo não teria implicado alguma real funcionalização às exigências da coletividade). 
Nos anos imediatamente posteriores à entrada em vigor da Constituição, as teses da funcionalização tiveram efeitos desagregadores. Dado ao contexto ideológico fortemente conflitivo no qual se inseriam as relações entre maiorias e minorias, parecia praticamente impossível de se propor a ideia de confiar a qualquer órgão público o controle sobre a adequação das ideias e das notícias circulantes aos interesses gerais da coletividade.

Por esses motivos, logo prevaleceu, na doutrina, a tese que atribui à função social da liberdade de pensamento um significado puramente metodológico (BARILE), ou existencial-descritivo: que, em essência, rebate a ideia individualista, segundo a qual a função social é entendida pelo exercício da liberdade, não podendo haver hipótese de restrição da mesma.

Em aplicação deste princípio, registra-se um consenso unânime sobre a inadmissibilidade de limites de submetam o exercício da liberdade de pensamento à manutenção da ordem democrática (segundo a ideia da democracia protegida, vide parágrafo 4.1).

Em outros termos, entende-se que não exista (PACE) uma ordem pública ideal, mesmo democrática, para defender, e que a Constituição viva também no exercício da liberdade de pensamento da parte que a contesta.

Sob tal perfil não se deve entender relevante, na matéria, o dever de fidelidade à República, estabelecido pelo artigo 52 da Constituição. As mesmas manifestações de pensamento direcionadas a divulgar a restauração da monarquia não poderiam ser consideradas proibidas por força do artigo 139 da Constituição, que veda a revisão da forma republicana, no momento em que esta última se dirige aos órgãos competentes ao exercício dos seus poderes e não aos indivíduos no exercício de suas liberdades.

Mais controverso é o problema posto com relação à XII disposição transitória final, que proíbe explicitamente a reconstituição do partido fascista: tal proibição pressupõe e traz consigo também a difusão dos ideais fascistas. Para alguns, tal disposição constitucional traria, na verdade, uma limitação de ordem ideal, justificada pela experiência histórica do nosso país, que faz presumir uma absoluta incompatibilidade entre o Estado democrático e a ideologia e a prática do fascismo (BARILE-DE SIERVO). A Corte Constitucional, chamada a pronunciar-se sobre a legitimidade do crime de apologia ao fascismo, previsto em lei devido à regulamentação da XII disposição transitória final, deu à norma impugnada uma interpretação restritiva, entendendo que (não obstante a criminalidade da conduta direcionada à restauração do partido fascista), não seria vedada a apologia ao fascismo, salvo quando se tratar de exaltação de tal alcance que possa ensejar uma reorganização do partido fascista, ou uma instigação, ainda que indireta, a adotar alguma daquelas condutas (Sentenças $n^{\text {os }} 1 / 1957$ e 74/1958). A Corte Constitucional, com isso, referiu que a proibição não é ao pensamento puro e simples, mas ao pensamento "que dá origem à ação" - segundo o critério aplicado em 
geral aos crimes de opinião, aos quais são entendidas como legítimas as manifestações de pensamento desde que, pela sua eficácia, sejam impassíveis de ensejar um princípio de ação (vide parágrafo 7.4).

Devido a tais eventos, a funcionalização é atualmente compreendida incompatível com a liberdade de pensamento individual. As posições funcionalistas que se encontram na jurisprudência comum e constitucional com respeito ao direito à crônica e de crítica ao jornalista devem imputar-se não tanto ao intuito de controle sobre o conteúdo da informação, quanto à tentativa de justificar, em vista do interesse geral à informação, a expansão desses direitos para além dos limites comumente admitidos à liberdade de pensamento individual (abaixo, parágrafo 8.2).

\begin{abstract}
Essas concepções (resultados, êxitos) da nossa constituição vigente dispensam de tratamento à denominada concepção institucional das liberdades de pensamento, que não se limita a enfatizar a função social (em particular, a função de integração dos indivíduos na vida da coletividade), mas ainda os conteúdos e a tutela historicamente determinada à evolução dos valores partilhados no seio de uma comunidade, com o efeito de abrir um espaço ainda maior ao legislador na interpretação, necessariamente elástica, da Constituição. As concepções (resultados, êxitos) potencialmente não-liberais desta concepção foram corretos propondo de referir os valores partilhados não à comunidade em abstrato (e, portanto, à prática às ideias e convicções da maioria), mas na "sociedade aberta" dos intérpretes da Constituição, ou seja, ao conjunto de sujeitos que na dialética entre eles e na relação com a mais ampla comunidade do pensamento jurídico-constitucional europeu, são chamados a interpretar as previsões constitucionais sobre liberdade (Häberle).
\end{abstract}

\title{
6.3 O Controverso Estatuto da Liberdade de Informação (remessa)
}

Ainda hoje, entretanto, permanece a controvérsia sobre o estatuto da liberdade de manifestação do pensamento exercida através da imprensa e de outros meios de comunicação de massa (ou seja da liberdade de informação e/ou de entretenimento, dada a impossibilidade de separar fielmente os dois fenômenos no conceito de massmedia, vide acima, parágrafo 4.3).

O contraponto entre a intervenção legislativa e a intervenção do juiz constitucional ainda não produziu um ponto de estabilidade, dando ensejo a controvérsias. Remete-se a capítulo posterior (parágrafo 7.8) a detalhada descrição dos termos da questão, que têm muitas faces, portanto é conveniente relatar aqui brevemente os pontos principais.

À luz das problemáticas clássicas e contemporâneas que a Constituição acolhe, o debate envolve inevitavelmente o equilíbrio que se instaura entre a garantia da liberdade e garantia da função social que a caracteriza ab origine: não só no seu aspecto externo (livre iniciativa nas relações com o poder 
público e com outras entidades privadas) como também no seu aspecto interno (liberdade do jornalista as suas relações com o proprietário e o diretor da revista).

O estatuto da liberdade de informação tornou-se então o banco de provas no o qual se confrontam as ideologias relativas à ideia de liberdade individual e, necessariamente junto, à ideia de Constituição. As posições a este respeito, com uma inevitável simplificação, são reduzidas a três.

1. A concepção individualista. De um lado, tem-se a concepção individualista, que coloca a liberdade do indivíduo como fundamento do poder estatal (ESPOSITO: é a liberdade de expressão que estabelece a democracia, não vice-versa) e atribui à Constituição a principal tarefa de limitar a ingerência deste poder na esfera soberana do indivíduo. Do pontode-vista hermenêutico, isso significa não só excluir, a priori, a funcionalização da liberdade de informação aos interesses gerais (em particular, à correta informação da opinião pública), mas também refutar a ideia que estes interesses possam servir como limites ou como valores de equilíbrio. No modelo liberal, como já sabemos, o interesse da coletividade à informação é indistinguível, ou melhor, é automaticamente satisfeito pelo exercício da liberdade e a sua melhor realização é assegurada pela sua mais ampla tutela.

No quadro da nossa Constituição, isso significa, particularmente, excluir que, quando a liberdade é exercida por uma empresa, se possa invocar a aplicação do artigo 41, que consentiria na colocação de limites no exercício da atividade dessa empresa, em razão não só da liberdade, dignidade e segurança humanas, mas também da utilidade social. Ao contrário, o valor que se depreende da liberdade de pensamento levaria a uma nova compreensão da tutela do artigo 21 , além da disciplina da empresa através da qual o pensamento é difundido, assegurando-lhe uma posição privilegiada (FOIS, CHIOLA).

Emerge claramente que a tendência de isolar a disciplina da liberdade de informação no interior do artigo 21, assumindo a disciplina da imprensa como modelo de máxima liberdade, rejeitando choques incertos com outros valores constitucionais, que poderiam entrar em conflito com o modelo liberal.

2. A concepção da "liberdade igual". De outro lado, tem-se a tese que considera a liberdade em relação não ao indivíduo abstratamente falando, mas ao homem inserido na realidade das suas condições de vida.

Isso comporta a aposição de limites à liberdade de manifestação do pensamento não só em vista da tutela abstrata da liberdade alheia, mas do efetivo e igual exercício das liberdades por parte de todos: até onde seja possível, de forma ativa, através do acesso, em primeira mão, aos meios de informação, e onde não seja possível, de forma (passiva e reduzida) de forma de interesse de receber o mais amplo leque de informações, como pressuposto para o exercício consciente dos direitos de liberdade e de participação conferida ao cidadão (BALDASSARE). Nesta ótica, compete ao legislador, 
sob a supervisão da Corte Constitucional, ponderar os princípios constitucionais em referência, pondo em jogo todas as disposições aplicáveis, nenhuma delas excluída (isso que vale em particular para o artigo 41, também ao artigo 43, que permite à lei reservar ao Estado a titularidade das empresas que tenham por objeto os serviços públicos essenciais e tenham caráter de proeminente interesse geral).

Ao fundo, emerge o entendimento que a Constituição não teria sido imprevidente em ignorar os novos meios de comunicação em massa, mas, em vez disso, teria enfatizado a impossibilidade de outorgar uma disciplina definitivamente válida, dando o justo espaço à necessária adequação entre a contínua evolução tecnológica e a totalidade das instâncias constitucionais. O valor exemplar do conceito de imprensa vem, nesta ótica, redimensionado, sendo devolvido às particulares condições históricas e econômicas que o originaram.

3. A concepção funcionalista. Com relação à massmedia, se propõe a tese da funcionalização, às instâncias superiores, de informação da coletividade ou ao "direito de informação ao cidadão" (LIPARI, COSTANZO). Entretanto, não é fácil admitir que uma liberdade possa ser tida como uma função, ou seja, traduzida no seu contrário. Parece preferível colocar em causa a própria existência da liberdade, quando (como se diz no caso da radiotelevisão via espaço) o particular almeja obter a disponibilidade de um recurso escasso: um privilégio legal; este, diferentemente da liberdade, exclui a fruição por parte de todos os outros sujeitos, além de parecer estar submetido a vínculos, não só de natureza externa ou modal, mas também de natureza interna ou de conteúdo, impostas pelo Poder Público (PACE).

\section{A RECONSTRUÇÃO DA GARANTIA CONSTITUCIONAL}

\subsection{Premissas Metodológicas}

As divisões ideológicas que emergem da doutrina, juntamente com algumas contendas terminológicas, fazem com que a reconstrução da liberdade de pensamento siga caminhos diversos também a nível dogmático: para alguns, a liberdade de pensamento representa um conceito unitário, ressalvada a possibilidade de discriminar a disciplina segundo os meios utilizados; para outros, algumas formas de manifestação gozam de uma disciplina privilegiada; para outros, ainda, deve-se fazer a distinção entre a liberdade individual de exprimir o pensamento e a situação subjetiva (mais limitada) das empresas de informação; para outros, ainda, entre todas as outras empresas de informação, somente as empresas de radiotelevisão ocupam uma posição distinta, que não contemplaria o gozo de uma liberdade.

Estas distinções, em certa medida, decorrem da evolução da jurisprudência constitucional, que, em uma primeira fase, considerou unitariamente a liberdade de manifestação de pensamento, reconhecendo, entretanto, a possibilidade de diversas disciplinas conforme o meio; em um segundo momento, fez aparecer, na disciplina do fenômeno informativo, em particular 
daquele radiotelevisivo, conteúdos originais, que poderiam ser atribuídas a uma diversa estrutura da situação subjetiva (a ser especificada).

Dada a natureza prevalentemente expositiva disso, é oportuno renunciar a uma estrutura sistemática, que pareceria, portanto, arbitrária; seria preferível seguir a evolução do direito vigente na sua substancial incompletude e falta de sistematicidade.

Em consequência, a definição da liberdade da manifestação do pensamento seguirá o caminho tradicional, considerando primeiramente o âmbito objetivo da garantia (a garantia do conteúdo, das modalidades dos meios de expressão e os limites a ele relativos, com particular referência ao princípio do pluralismo informativo), seguidamente do aspecto subjetivo (com particular referência ao status do jornalista).

\section{2 Âmbito Objetivo da Garantia Constitucional}

\subsection{Relação com as Outras Liberdades}

A definição do objeto da garantia constitucional é particularmente desafiadora, porque a fórmula constitucional se presta a incluir uma gama muito vasta de suportes fáticos (o pensamento manifestado com qualquer finalidade e sob qualquer modalidade, aí compreendidos os comportamentos expressivos, como o ato de queimar a bandeira, por exemplo, ver acima), que se torna imensa e abrange todos os objetos através dos quais o pensamento toma forma (manuscritos, livros, filmes), bem como a atividade instrumental preliminar à manifestação, como a atividade final à difusão, como a atividade tipográfica, de venda e assim por diante.

Relativamente a uma hipótese primeiramente posta em foco, a disciplina constitucional de outras liberdades: em particular, com já se disse, da liberdade de comunicação e correspondência. Recai sob a tutela do artigo 15 o pensamento dirigido a destinatários determinados através do uso de meios que garantem o sigilo (como o telefone e o correio). Também o uso da internet constitui uma forma de comunicação reservada, a menos que o usuário não escolha voluntariamente formas que visem à manifestação pública do próprio pensamento.

Deve também ser analisado que, quando a manifestação do pensamento, como frequentemente se dá, se exercita através de reunião ou de associação com outras pessoas, a esta se aplica a disciplina do artigo 21, porquanto se refere ao pensamento manifestado e aquela dos artigos 17 e 18, para o que diz respeito às atividades que o dão suporte.

\subsection{Garantia do Conteúdo}

Vindo agora a definição do objeto da garantia constitucional, isso se identifica, antes de tudo, como garantia da liberdade do conteúdo da manifestação do pensamento expresso. É preciso ter presente que as abordagens dogmáticas são duas: uma abordagem de definição, que tende a isolar o que se deve compreender como "pensamento", tutelado pela 
Constituição daquilo que não é, além de definir os limites de uma vez por todas; outra abordagem de natureza valorativa, que tende a enfrentar diferentes diplomas e, portanto, diferentes limites, segundo a matéria objeto da manifestação.

Este último foi sustentado, na nossa doutrina, propondo-se a distinção entre pensamento comum, protegido pelo artigo 21 da Constituição, e formas de pensamento privilegiadas, enquanto relativas a matérias particularmente tuteladas pela Constituição. Estas seriam o pensamento religioso, o pensamento artístico, científico e o pensamento político, privilegiados em relação à finalidade de exercício da liberdade de consciência, de progresso espiritual e científico, de participação dos cidadãos na formação da política nacional (artigos 19, 33 e 49) (FOIS; no mesmo sentido, CERRI, que acrescenta o direito de crônica, enquanto inerente ao funcionamento desta democracia, ex. artigo $1^{\circ}$ da Constituição; o pensamento expresso em juízo, no exercício do direito de ação e de defesa, nos termos do artigo 24 da Constituição e o pensamento expresso no exercício de funções representativas nacionais ou locais, conforme artigo 68 e 112 da Constituição. Sobre este último ponto, vide abaixo, parágrafo 8.1).

A tese encontra um apoio textual somente para a liberdade de arte e da ciência, que a Constituição não impõe explicitamente o limite do bom costume (frise-se que a referência aos espetáculos contrários ao bom costume, no artigo 21, último parágrafo, da Constituição, depõe em sentido contrário, desde que tais espetáculos, de regra, não deixam de ser manifestações artísticas). Em concreto, o problema se põe sobretudo para as manifestações artísticas, por força do artigo 528 do Código Penal, que pune a prática de publicações e espetáculos obscenos. $\mathrm{Na}$ jurisprudência, o problema é tradicionalmente enfrentado mediante aplicação do brocardo "a arte não é obscena, o obsceno não é arte", o que dá ensejo a muitas críticas, dado ao fato de que o tema é altamente discutível. De uma forma mais radical, observa-se que o artista pode muito bem recorrer ao obsceno, se entende que isso seja essencial à sua obra; de forma que o único limite oponível a isso seria aquele derivado da tutela de menores (RIMOLI). Este modo de pensar surge da convicção que a expressão do pensamento disciplinada pelo artigo 21 não está vinculada como esta última a assumir uma forma inteligível a todos, mas somente refletir o mundo interior do artista.

$\mathrm{Na}$ verdade, esta tese não possui raízes em nosso ordenamento, enquanto abre um perigoso espaço de discriminação entre o pensamento sublime e o pensamento vulgar, entre o pensamento atento e o pensamento fútil.

A jurisprudência constitucional preferiu uma abordagem definitiva, que outorga uma garantia menos elástica, mais rígida, estabelecendo um equilíbrio satisfatório entre as manifestações incluídas e as excluídas da garantia constitucional. É pressuposto deste equilíbrio, como já referido, 
a subtração de ampla garantia constitucional da disciplina dos meios (vide abaixo, parágrafo 7.7).

Foi excluído, primeiramente, o pensamento subjetivamente falso, com base na explícita referência constitucional à expressão do "próprio" pensamento (não, portanto, a uma notória mentira). Disso se deriva a legitimidade das disciplinas que vedam a fraude, o dolo e o embuste.

Sobre a mesma base, a doutrina entendeu por excluir da tutela constitucional o pensamento que não se pode entender como "próprio", enquanto não original, mas mera repetição ou reprodução do pensamento de outros, em prol da legitimidade das leis que tutelam o direito autoral e a propriedade literária.

Com referência, pode-se objetar que não existe um pensamento verdadeiramente original, que não se reconecta, ainda que inconscientemente, com a elaboração anterior, bem como que as idéias não são propriedade daquele que as concebeu, mas são destinadas a circular e de serem feitas também propriedade de outros. Por tais motivos, alguns limitariam a tutela dos direitos do autor somente ao aspecto econômico, segundo o sistema anglo-saxônico de "copyright".

Também foi excluído o pensamento quando o mesmo se traduz em um "princípio de ação" (FOIS). Sobre a base desta fórmula, foram suprimidos os crimes de opinião previstos no Código Rocco, declarando como ilegítimas algumas normas que puniam a mera expressão do pensamento (instigação ao ódio entre as classes sociais; propaganda contrária ao sentimento nacional e assim por diante), além de restringir, por via interpretativa, o campo de ação de outras normas, de forma a referir que somente as manifestações de pensamento que são idôneas a ensejar um concreto perigo de ação: algo como apologia ao crime, por apologia ao fascismo (a qual já foi mencionada acima, parágrafo 6.2), mas também em parte para o vilipêndio (sobre o qual vide abaixo, parágrafo 7.5).

Esta operação interpretativa é criticável porque negligencia que qualquer manifestação do pensamento é direcionada a incidir sobre o comportamento, bem como sobre as convicções de outros (every idea is an encitment, diz a doutrina norte-americana). Excluir da tutela constitucional o pensamento "que se faz ação" equivale, em outras palavras, a admitir a permanência - também no quadro da Constituição, que de fato não o menciona - de um limite de ordem pública ideal, visando a impedir pelo menos as manifestações de desobediência que se concretizam no incitamento ao cometimento de crimes (PACE).

A categoria dos crimes de opinião ampliou-se em virtude das normas que punem o incitamento ao ódio por motivos étnicos, raciais, nacionais e religiosos (Leis $n^{\text {os }} 654$, de 13 de outubro de 1975 e 205, de 25 de 
junho de 1993). A disciplina em questão goza, no entanto, de uma cobertura internacional (que se reporta à Declaração dos Direitos do Homem e à convenção da qual ela adveio) e reatou, em nosso ordenamento, com a razão antifascista e anti-racista da XII disposição constitucional transitória final da Constituição.

A Corte excluiu também da tutela do artigo 21 o pensamento, quando se visa unicamente a finalidade de lucro, tomando a forma de propaganda comercial. Esta recai, de acordo com a Corte Constitucional, sob a tutela do artigo 41 da Constituição (liberdade de iniciativa econômica) e sofre os limites desta última (Sentença nº 68/1965).

(Sobre o ponto, vide as críticas de FOIS e agora de ZACCARIA, com particular referência ao fato de que, no dia de hoje, a mesma propaganda política toma a forma de publicidade comercial. Além disso, não se pode olvidar que, por vezes, a publicidade constitui forma de expressão artística).

Basicamente é também a escolha feita pela Corte Constitucional em razão do direito de crônica, que foi incluído por completo na garantia do artigo 21 (Sentença no 105/1972). Como a doutrina já havia constatado, é na verdade impossível distinguir a notícia enquanto tal do pensamento daquele que a veicula (PALADIN).

Foram, além disso, incluídos na garantia constitucional os denominados comportamentos expressivos.

Em contrário, se sustenta que a Constituição menciona explicitamente os comportamentos relativos à liberdade de religião (liberdade de professar o próprio credo e de praticar os ritos a ele referentes) e que, estendendo de tal modo o alcance do artigo 21, se concluiria por impedir ao legislador a disciplina de qualquer comportamento (CHIOLA).

Sobre a base de um princípio hermenêutico aplicável a todas as liberdades, entende-se, por fim, inclusa na garantia constitucional a liberdade de não manifestar o pensamento. A Corte, na Sentença $n^{\circ} 12 / 1972$, declarou o "direito de não revelar a própria convicção"; enquanto a doutrina elaborou um conceito mais amplo de "direito ao silêncio", incluindo também o direito de não fornecer informações ou notícias referentes à própria pessoa ou a fatos dos quais se tenha ciência.

Pode-se discutir se esta configuração doutrinária não seja extensiva demais, em colocar sob o abrigo do artigo 21 disciplinas diversas, como a obrigação de testemunhar em juízo dizendo a verdade (obrigação que, contudo, não vale ao acusado, o qual não pode ser obrigado a admitir fatos que são ao mesmo prejudiciais), a obrigação de fornecer informações 
em havendo relevância estatística, a obrigação dos fabricantes da indústria farmacêutica e de produtores de bens de consumo de fornecer indicações sobre a composição e o uso correto do produto. De fato, parece de todo diversa a revelação de fatos pessoais e privados (que se deve provavelmente colocar sob a tutela da privacidade), da descrição de circunstâncias e acontecimentos que não dizem respeito diretamente ao indivíduo. E enquanto é razoável exigir o respeito dos requisitos constitucionais rigorosos para a intervenção legislativa que limita a esfera privada do indivíduo ( seja ela protegida pelo artigo 14 ou pelo artigo 21), parece que para os outros seja suficiente o respeito à reserva imposta pelo artigo 23 em relação à imposição de prestações pessoais (SANDULLI).

\subsection{Limites Relativos ao Conteúdo do Pensamento Expresso}

Uma vez definido o objeto da garantia constitucional, excluindo-se, de um lado, as ideias protegidas por outras normas constitucionais e, de outro, as ideias não protegidas de forma absoluta pela Constituição (e remetidas portanto, à discricionariedade legislativa), trata-se de individualizar os limites nos quais as primeiras estão sujeitas.

\section{Limite do bom costume}

O artigo 21 da Constituição menciona explicitamente o limite do bom costume, prevendo a sua tutela a adoção de medidas preventivas e repressivas (último parágrafo). Como já sabemos, em relação ao material informativo, tal limite legitima a medida do sequestro, mesmo que preventivo (acima, parágrafo 5.2); em relação aos outros meios de manifestação do pensamento, legitima-se, por sua vez, a submissão a várias outras formas de controle. Lembramos que atualmente apenas os espetáculos cinematográficos são submetidos à censura (ou seja, à prévia aprovação do conteúdo da obra), que pode acabar em uma proibição total de divulgação ou ainda na imposição de limite à exposição para menores.

A Corte Constitucional interpretou a tutela do bom costume como em referência ao pudor sexual das pessoas (além da sensibilidade dos menores, em razão da específica previsão do artigo 31 da Constituição), em vez de compreendê-la como deferência à moral, ou melhor, à moral da maioria. Em uma recente sentença, estendeu-se, porém, o bom costume à tutela da dignidade da pessoa humana, estabelecido pelo artigo $2^{\circ}$ da Constituição, embora observando que esta última está compreendida, em um sentido pluralístico, como "o que é comum a diversas morais do nosso tempo" (Sentença $n^{\circ}$ 293/2000).

A Corte igualmente colocou sob a égide da tutela do bom costume, ao menos inicialmente, alguns crimes de opinião. Assim, o crime de "incitação à prática contra a procriação" foi considerado como ilegítimo, enquanto limitado à "propaganda que pelo modo e pelo lugar viola o bom costume" (Sentença $n^{\circ}$ 9/1965); assim, a incriminação penal da blasfêmia foi justificada com referência a um fenômeno de mau costume (Sentença $n^{\circ}$ 14/1973). 
Posteriormente, a Corte Constitucional declarou como ilegítimo o primeiro crime (Sentença $n^{\circ}$ 49/1971); o segundo, hoje despenalizado, foi entendido novamente como ilegítimo, por estender a proteção oferecida às divindades de todas as religiões, não só da católica (Sentença n 440/1995). As críticas com referência a isso são feitas seja pela extensão do tipo penal (que não é dado à Corte), seja pela irrelevância, entendida pela Corte, da violação ao artigo 21 da Constituição. A Corte, neste aspecto, fez valer o igual direito à liberdade religiosa, mas não a liberdade de manifestação do pensamento.

\section{Os limites implícitos}

Como se sabe (acima, parágrafo 5.1), a liberdade de manifestação do pensamento sofre, além do limite expresso do bom costume, todos os outros limites que devem ser inferidos, via interpretativa, da tutela constitucional dos bens individuais e coletivo, permanecendo ainda a proibição, para o legislador, de criar novos e ulteriores.

No nosso ordenamento, esta afirmação teve um preciso significado de ruptura com a legislação de origem fascista, que subordinava a manifestação do pensamento à tutela de incontáveis outros interesses. A mesma Corte teve dificuldade em reconhecer essa ruptura, valendo-se, em um primeiro momento, de limites que a Constituição não menciona (como a tutela da ordem pública ou da tranquilidade dos consorciados), e somente mais tarde reconhecendo que os limites da manifestação do pensamento devem ser baseadas exclusivamente na Constituição.

Sob um atento escrutínio, o sentido de tal informação se revela largamente ambíguo. Com efeito, as previsões constitucionais autorizam abstratamente uma quantidade quase incontável de limites; enquanto a proteção de alguns bens, que estão particularmente ameaçados pela manifestação do pensamento, há a dificuldade de encontrar uma direta inserção na Constituição.

Trata-se, portanto, de verificar quais são, entre todos, os bens constitucionalmente protegidos que podem legitimar a imposição de limites à liberdade de manifestação do pensamento. A este respeito, é ainda mais decisiva a jurisprudência constitucional, que, se destacando do exemplo de outros países, como a Alemanha, não estabeleceu, no âmbito da Constituição, uma hierarquia de valores definitivamente válida, mas operou em equilíbrio entre os artigos 21 e as outras normas constitucionais casuisticamente.

Isso é considerada uma felix culpa da jurisprudência (e da doutrina) italiana (Paladin), no momento em que se assegura a máxima abertura às exigências constitucionais envolvidas. O ponto fraco está no fato que o critério do juízo é dificilmente previsível e pode levar, por vezes, a contestações. Assim, tem-se, por exemplo, por limite de ordem econômica, que a Corte aplicou na Sentença $n^{\circ}$ 87/1966, e que a doutrina criticou, pelo seu caráter genérico, também pela sua inferioridade qualitativa a respeito da tutela da liberdade de manifestação do pensamento. 


\subsection{Os limites à tutela de outros direitos constitucionais}

Deve-se salientar que os limites em questão se aplicam tanto com relação à manifestação do pensamento em geral quanto ao direito de crônica em particular, assumindo, entretanto, em relação a este último, uma extensão diversa. As peculiaridades referentemente à posição do jornalista serão tratadas a parte, posteriormente, parágrafo 7.2.

Entre esses, leva-se em consideração, em primeiro lugar, a honra e a reputação, que se depreendem do reconhecimento do próprio princípio da dignidade dos cidadãos, garantida pelo artigo $3^{\circ}$, parágrafo primeiro, da Constituição.

Em atuação destes limites, é considerada legítima a punição dos crimes de injúria e de difamação. Deve-se recordar que por crime de difamação o nosso ordenamento jurídico não admite a regra da exceptio veritatis, ou seja, não admite ao imputado a comprovação da verdade do fato referido. Isso significa que a tutela da honra prevalece sobre a liberdade de manifestação do pensamento (tal prevalência é, porém, fortemente atenuada nos limites do direito de crônica jornalística, onde são observados determinados requisitos).

A jurisprudência também configurou um direito "à identidade pessoal", do que deriva a ilicitude da atribuição de fatos ou declarações que, ainda que não desprezíveis, não correspondem ao comportamento e às convicções do sujeito (Corte Constitucional, Sentença $n^{\circ}$ 13/1994).

A correção ${ }^{9}$ é o instrumento específico através do qual o indivíduo pode tutelar estes direitos, almejando que uma declaração dele próprio seja inserida gratuitamente no periódico ou seja transmitida pelo emitente que tenha divulgado notícias a ele referentes e que lhe sejam lesivas (no caso de transmissão radiotelevisiva, exige-se também que as notícias sejam inverídicas) (art. $8^{\circ}$ da Lei $n^{\circ}$ 47/1948 e art. 10 da Lei n 223/1990.

Em segundo lugar, vem o direito à privacidade da pessoa, como direito à manutenção de uma esfera de intimidade, protegida da curiosidade de terceiros, que envolve as notícias e a imagem que dizem respeito à pessoa e sua vida privada. Este direito se depreende do artigo 14 da Constituição, que tutela o domicílio, e, em um aspecto mais geral, a proteção constitucional do livre desenvolvimento da personalidade (artigo $3^{\circ}$, segundo parágrafo), a qual não poderia se dar se todos os aspectos da vida do indivíduo fossem dados ao conhecimento público (MAZZIOTTI).

\footnotetext{
${ }^{9}$ O texto original faz referência ao termo rettifica que consiste em uma correção de uma informação inexata publicada em um meio de comunicação. Parece uma figura semelhante à que se comumente se vê em nossos meios de comunicação em que se denomina errata, porém de autoria do próprio titular do direito lesado. (N.T.)
} 
Quanto à imagem, existe um específico direito à privacidade, tutelado pelo artigo 10 do Código Civil, que condiciona a possibilidade de difusão à anuência daquele que teria sua imagem transmitida (ou à anuência dos herdeiros do mesmo). O rigor desta norma se justifica pelo efeito peculiar da imagem, que tende a impressionar bem mais que qualquer outra descrição de aparência.

Além disso, a imagem é considerada como manifestação do pensamento, pelo menos na opinião da Corte Constitucional, somente quando vinculada a uma mensagem ou a uma notícia (Sentença no 122/1970). Esta condição também se aplica no trabalho dos fotógrafos e dos profissionais do cinema, como efeito da atribuição aos mesmos da condição de jornalista. A jurisprudência entende que se pode falar de crônica, relativamente às imagens, quando estas são aptas a comunicar uma mensagem ou uma notícia, sem a necessidade de um comentário falado ou escrito (Corte de Cassação, 18 de janeiro de 1986, n 330)

A privacidade se conecta, na jurisprudência, ao denominado direito ao esquecimento, ou direito do infrator de mudar sua vida, considerada como a pretensão de não ter contra si invocados fatos pregressos que possam impedir a remissão de quem foi considerado culpado de graves delitos.

Considera-se que a disciplina relativa ao tratamento dos dados pessoais (constante no acima citado Decreto Legislativo $n^{\circ} 196$, de 30 de junho de 2003 - parágrafo 5.2) oferece novas formas de tutela aos direitos individuais que podem ser violados pelo exercício da liberdade de manifestação e difusão do pensamento. O interessado pode dirigir-se ao órgão que ostenta a atribuição de garantia do direito em exame a fim de requerer medidas inibitórias em regime de urgência, sem prejuízo do direito ao ressarcimento do dano (ainda que não patrimonial - que de regra é reconhecido pela lei somente em se tratando de fatos que tipificam crimes).

A tutela da privacidade individual e familiar, também a tutela específica da liberdade religiosa e do direito à tutela jurisdicional, conectam-se ao limite do segredo profissional, que impede aos ministros de confissão religiosa, médicos e advogados de revelarem aquilo que têm conhecimento em razão de seu ofício, ainda que sejam chamados a depor em juízo sobre tais fatos.

\subsection{Limites à tutela de bens coletivos protegidos constitucionalmente}

Como antes já foi referido, a Corte Constitucional foi objeto de críticas por ter, no passado, aplicado limites não previstos pela Constituição, e além disso com uma natureza demasiadamente indeterminada, como a ordem pública e a tranquilidade entre os sócios. Esta jurisprudência foi em seguida superada, e, em virtude disso, atenuaram-se as críticas, entendendo-se que as fórmulas indicadas podiam, na maior parte dos casos, ser substancialmente enquadradas em limites constitucionais específicos (PALADIN), ainda que, na prática, a identificação desses limites não seja isenta de dúvidas. 
Entre estes está, em primeiro lugar, o limite imposto à manifestação de pensamento em nome do prestígio das instituições e das pessoas que as representam, o que se concretiza nos crimes de vilipêndio ${ }^{10}$ (à bandeira, à República, à religião Católica) e de ultraje ${ }^{11}$. Trata-se de típicos crimes de opinião, que se mantiveram em vigor por muito tempo recorrendo à interpretações redutivas ou corretivas.

A Corte entendeu pela não-inconstitucionalidade da punição do vilipêndio, desde que ela se dirija não à crítica, ainda que severa, às instituições, mas à manifestação do pensamento "que se faz ação", incitando a desobediência (Sentença $n^{\circ}$ 20/1974).

Também o crime de ultraje a servidor público - atualmente revogado era considerado legítimo, embora admitindo que considerar este delito mais gravoso comparativamente à injúria endereçada ao simples cidadão exprimia "uma concepção autoritária do Estado".

$\mathrm{O}$ vilipêndio à religião católica teve sua previsão justificada, em um primeiro momento, em termos de tutela, não pela autoridade espiritual da Igreja, mas dos sentimentos religiosos nutridos pela maioria dos italianos; recentemente, porém, foi declarado ilegítimo, por violação ao princípio da laicidade do Estado (Sentença $n^{\circ}$ 508/2000).

A tendência de reformular o bem protegido pelo crime de vilipêndio direcionando-lhe à proteção dos sentimentos dos cidadãos - difilmente se subtrai ao risco de impor valores que não são efetivamente partilhados por todos, além de desconsiderar o fato de que a sobrevivência da ordem constitucional democrática reclama aos cidadãos um alto nível de tolerância, mesmo nos confrontos de ideias que suscitam indignação (v. acima, parágrafo 3 , sobre o vilipêndio à bandeira).

Aparecem em segundo lugar os diversos bens constitucionais que constituem o fundamento do "limite dos segredos": a defesa dos interesses vitais da Nação, que legitima o segredo de Estado; a funcionalidade da Administração Pública, que baseia o segredo funcional (ou segredo de ofício); a atuação eficaz da função jurisdicional, incluindo a presunção de inocência e a tutela dos menores que figuram nos processos judiciais, o que enseja o segredo de justiça.

Neste aspecto, é necessário que se façam algumas distinções.

O "limite dos segredos" representa, antes de tudo, um limite à busca e obtenção das notícias, recaindo portanto na problemática referente à assim

\footnotetext{
${ }^{10}$ No direito penal italiano, fala-se em vilipêndio em referência a alguns crimes que consistem em manifestações de desprezo verbal em relação a determinados sujeitos, particularmente as instituições do Estado, de confissão religiosa e incluindo os mortos. (N.T.)

${ }^{11} \mathrm{O}$ Código Penal Italiano traz alguns tipos penais que englobam a denominação ultraje (oltraggio), que, em geral, significa ofensa. Há o crime de ultraje contra servidor público (antes previsto no artigo 341 do Código Penal Italiano, atualmente revogado na sua tipificação original), ultraje contra juiz em audiência (artigo 343 do Código Penal), entre outros (estes estão previstos no capítulo referente aos delitos cometidos contra a Administração Pública. (N.T.)
} 
denominada inspectio (que é um pressuposto da manifestação do pensamento, mas não se confunde com a mesma).

Sob este aspecto, os segredos são avaliados sobretudo com relação ao princípio da publicidade e da transparência que estão na base do funcionamento do princípio democrático. Com base neste princípio, deve-se presumir a existência de um direito do cidadão de ser informado, por parte do Poder Público, sobre tudo aquilo que diga respeito à gestão da coisa pública, a menos que com isso não se ponha em risco concreto o funcionamento da máquina estatal (ou a tutela de outros direitos individuais, como é o caso do segredo de Justiça).

Sobre o direito do cidadão de buscar e receber as informações e sobre o direito de ser informado por parte dos órgãos de informação, v. abaixo, parágrafo 7.10 .

Outro é o aspecto referente à manifestação do pensamento propriamente dita. A proibição de divulgar fatos cujo conhecimento foi obtido de forma legítima pode basear-se apenas na extrema necessidade de defesa do país e do sistema democrático (o qual se pretende que seja considerado indivisível: a proibição não pode jamais se estender a fatos subversivos à ordem constitucional) (Sentença $n^{\circ}$ 86/1977 da Corte Constitucional Italiana).

Referentemente a isso, faz-se necessária a diferença entre a situação do cidadão comum e aquela dos funcionários públicos em relação às notícias de que tiveram conhecimento em razão do próprio ofício. Os últimos estão sujeitos a um particular dever de fidelidade, como é o exemplo do artigo 54, segundo parágrafo, da Constituição Italiana, que os impede de manifestar livremente seu pensamento (abaixo, parágrafo 8.1) ${ }^{12}$.

Em terceiro lugar, são postas em consideração as normas constitucionais que estabelecem limites ao denominado direito ao silêncio, como a obrigação de testemunhar em juízo, a qual também tem como fundamento o interesse em uma atuação eficaz do Poder Judiciário.

Como já foi dito, estes podem ser considerados como limites à manifestação do pensamento enquanto digam respeito às próprias convicções e opiniões; por outro lado, são limites à privacidade, ou limites à liberdade empresarial, ou ainda limites à liberdade moral prevista pelo artigo 23 da Constituição.

\subsection{Garantia das Modalidades Expressivas}

Quanto às modalidades da manifestação do pensamento, deve-se ter presente que, por constante jurisprudência neste sentido, oriunda da Corte

\footnotetext{
${ }^{12} \mathrm{O}$ segundo parágrafo do artigo 54 da Constituição Italiana estabelece que os cidadãos a quem são confiadas funções públicas têm o dever de desempenhá-las com disciplina e honra, prestando juramento nos casos estabelecidos pela lei. (N.T.)
} 
Constitucional, o legislador é livre para disciplinar a forma e o modo de exercício das liberdades, na medida em que isso seja indispensável para a tutela de outros bens tutelados constitucionalmente.

A verdade é que, em se tratando da liberdade de pensamento, a forma é particularmente relevante, uma vez que incide sobre a eficácia do pensamento expresso, fazendo com que tudo se torne uma unidade com o conteúdo. Por este motivo, fica difícil limitar o pensamento expresso de forma não-civilizada ou brutal (a menos que não seja ofensivo às pessoas ou às instituições), mesmo porque dessa forma se criaria uma discriminação entre as manifestações populares, que são mais ingênuas e grosseiras, e o pensamento culto (FIORE).

Sobre o limite da formalização, imposta ao jornalista, ver abaixo, parágrafo 8.2.

\subsection{Garantia dos Meios e Limites Relativos}

Por meio se entende tudo aquilo que serve propriamente para exprimir (papel, filme, partitura musical) ou, sucessivamente, para divulgar o pensamento expresso (alto-falantes, máquinas tipográficas, sistemas de transmissão televisiva, entre outras).

Como já se sabe, a Constituição garante a liberdade da manifestação do pensamento "através do escrito, da palavra e de qualquer outro meio de difusão", ou seja, tutela explicitamente (e é o único caso) os meios necessários para o exercício da liberdade.

Comumente, não é aceita a ideia de que com isso a Constituição tenha pretendido garantir a todos a disponibilidade destes meios (pelos motivos já expostos acima, parágrafo 4.2, que se opõem ao reconhecimento, neste campo, de uma liberdade positiva, se não em uma forma reduzidíssima).

O único direito geral ao uso do meio (por outrem) ocorre na hipótese da correção ${ }^{13}$, que além da função de tutela aos direitos individuais (acima, 7.5), fornece ao cidadão a possibilidade de contribuir com uma maior completude da informação.

Há, pois, um direito de acesso ao meio televisivo em favor dos sujeitos políticos, referentemente aos denominados programas de comunicação política, no qual devem poder participar de forma gratuita e em condições de igualdade. Este direito é garantido, contemporaneamente, a tais sujeitos, que têm paridade de chances na competição eleitoral, e ao interesse geral à "formação da consciência política do cidadão" (abaixo, 7.13).

O acesso ao serviço público radiotelevisivo, com programas da parte de associações e grupos "de relevante interesse social" - a regra da Lei $n^{\circ} 103 / 1975$ não é considerada um direito, nem mesmo um interesse

\footnotetext{
${ }^{13}$ Ver nota número 5, acima, que faz referência ao termo ora utilizado. (N.T.)
} 
legítimo, mas uma mera "expectativa politicamente protegida", uma vez que submetida à valoração inquestionável da Comissão parlamentar de vigilância.

Em compensação, alguns entendem que a referência expressa aos meios implica a garantia, a todos, de apropriar-se e usar livremente os instrumentos de difusão; o legislador seria assim obrigado a adaptar o regime jurídico de tais meios de modo a autorizar a aquisição da propriedade e o exercício da atividade sem nenhuma referência aos limites previstos pelos artigos 42 e 43 da Constituição.

A Corte Constitucional, entretanto, rejeitou esta tese, e subordinou o direito ao uso dos meios a uma articulada série de condições, que dizem respeito tanto às suas características especiais quanto à necessidade de garantir um igual gozo dos mesmos por parte de todos, além da tutela de interesses outros constitucionalmente tutelados (Sentença nº 105/1972).

Entre estes interesses, é evidenciado e colocado como padrão de uso da discricionariedade legislativa, o "interesse geral à informação, indiretamente protegido pelo artigo 21 da Constituição", que implica a necessidade de assegurar, da melhor forma possível, "a pluralidade das fontes informativas".

Dessa forma, a Corte distingue, implicitamente, o estatuto dos meios de comunicação de massa daquele outros meios de manifestação do pensamento. Esses últimos permanecem tutelados pelo princípio da máxima liberdade no acesso e no uso, em condições de igualdade, salvo a tutela de outros bens constitucionalmente protegidos. Por exemplo, o uso de alto-falantes não poderia estar reservado a alguns indivíduos (em hipótese, a alguns partidos políticos), mas pode ser proibido o seu uso à noite, em vista da tutela da saúde dos cidadãos.

A mass media, entretanto, está sujeita a um regime que contempla a norma do próprio artigo 21, o princípio do pluralismo informativo. Parece, portanto, que, aqui, a Corte desenvolve o princípio que se depreende do quinto parágrafo do artigo 21 (ver acima, parágrafo 5.2), atribuindo ao valor social da informação um papel não só descritivo (no exercício da liberdade de pensamento), mas também prescritivo, apto a legitimar, referentemente ao uso desses meios, limites específicos.

Como agora se verá, a referência a este enunciado implícito no artigo 21 conduziu a Corte a uma elaboração complexa e inovadora, que, frise-se, corresponde às diretrizes aplicadas em todos os outros países europeus.

A Carta dos direitos fundamentais da União Europeia (denominada Carta de Nice), aprovada no ano de 2000, estabelece expressamente que "a liberdade da mídia e o seu pluralismo serão respeitados." (artigo 11, segundo parágrafo). 


\subsection{O Princípio do Pluralismo Informativo}

O trabalho de reconstrução da Corte deu-se com referência ao setor radiotelevisivo, considerando que aqui (conforme abordado acima, parágrafos 4.2 e 4.3) a ordem econômica e técnica favorece a concentração em poucas mãos de um meio que pode, fortemente, afetar a opinião pública.

É verdade que a evolução tecnológica enseja a criação de condições para um efetivo pluralismo (abaixo, 7.12); mas mesmo que se admita que os novos sistemas de comunicação se propaguem adequadamente entre os cidadãos, também considerando que há muitas novas empresas prontas para ocupar os novos espaços criados, o perigo que se surjam posições dominantes lesivas ao pluralismo não se pode entender como superado.

Mostra-se, portanto, indispensável seja retraçada a jurisprudência constitucional que se formou a esse respeito, que passou por fases ou estágios diversos.

1. O pluralismo interno ao serviço público radiotelevisivo: em um primeiro momento, a Corte entendeu pela impossibilidade de se outorgar às empresas privadas o uso desse meio, diante da limitação das frequências disponíveis, o que acabaria por ensejar a criação de um oligopólio. Por consequência, estabeleceu-se a legitimidade do monopólio estatal, com base no artigo 43 da Constituição $0^{14}$, sob o fundamento de assegurar, através do serviço público, as condições que os entes privados não poderiam satisfazer, tais como a objetividade, a imparcialidade e a completude da informação, além da irradiação das transmissões sobre todo o território nacional (Sentença $n^{\circ}$ 59/1960).

Esta análise foi, em seguida, retomada e aprofundada, colocando, na legitimidade do monopólio, duas precisas condições: de um lado, a previsão de formas específicas de acesso ao meio por parte das vozes e opiniões provenientes da sociedade; de outro, a subtração, ao governo, do controle sobre a sociedade concessionária do serviço público. Desse modo, a Corte prefigurava a abertura do meio, seja a todas as opiniões políticas representadas no Parlamento, seja às opiniões minoritárias, expressões de grupos sociais (Sentença n 225/1974).

Em cumprimento a esta sentença, a Lei de Reforma $n^{\circ}$ 103/1975 submeteu a RAI ao controle de uma comissão bicameral composta por todos os partidos representados no Parlamento, a quem também foi atribuída a tarefa de autorizar o uso do meio, através de transmissões, às associações políticas, sindicais e culturais, além de outros grupos de relevante interesse social (o tempo reservado a essas transmissões é reduzidíssimo).

\footnotetext{
${ }^{14} \mathrm{O}$ artigo 43 da Constituição Italiana estabelece que, para fins de utilidade pública, a lei pode reservar ou transferir ao Estado ou a entes públicos atividades referentes a serviços públicos essenciais, fontes de energia ou a situações de monopólio, desde que presente o interesse geral. (N.T.)
} 
2. O pluralismo externo. Logo após, a Corte deu início à queda do monopólio estatal, entendendo superado, pela evolução tecnológica, o argumento baseado na escassez de frequências utilizáveis, adotando, então, um critério baseado na acessibilidade econômica do meio, através de um número suficientemente amplo de sujeitos.

Com base neste critério, as transmissões via espaço em escala local foram liberalizadas (Sentença $n^{\circ}$ 202/1976); já em se tratando de transmissões em escala nacional, a Corte entendeu que o monopólio poderia ser superado, através de disciplina legislativa, na condição de se adotar uma adequada disciplina antitruste. Isso evitaria a produção de concentrações de monopólios ou oligopólios não só entre as empresas radiotelevisivas, mas também entre estas e as empresas editoriais e publicitárias. Além disso, limitaria o recurso à publicidade televisiva, de forma a impedir esta última de secar as fontes de financiamento da imprensa (Sentenças $n^{\text {os }}$ 148/1991 e 826/1988).

Dessa forma, a Corte desenhou um quadro global do sistema informativo, no qual o pluralismo "interno", já realizado em âmbito do serviço público radiotelevisivo, deve completar-se com o pluralismo "externo", assegurado pela concorrência entre várias empresas radiotelevisivas provadas, integrando-se em um maior e geral pluralismo dos principais meios informativos, no qual se assegura posição de destaque à imprensa.

É importante enfatizar que a Corte, em face da relutância do legislador, destacou a necessidade de formatar tal quadro, como imperativo constitucional baseado no "direito do cidadão à informação" (Sentença nº 826/1988).

3. Requisitos da ordem pluralística: Instada a avaliar a constitucionalidade das leis que reconheceram o sistema televisivo misto em nível nacional, a Corte teve a oportunidade de precisar o significado do termo pluralismo, seja ele externo ou interno.

Em se tratando do primeiro, entendeu a Corte que, no sistema radiotelevisivo, o mesmo deve se dar com a presença do máximo número possível de vozes diversas, e que, portanto, não se pode exaurir no concurso entre um só ente público e um só ente privado (Sentenças ${ }^{\text {os }} 112 / 1993$, 420/1994 e 466/2002).

Referentemente ao pluralismo "interno", compreendido como a abertura às vozes provenientes da sociedade, a Corte definiu que ele diz respeito inclusive à emissão radiotelevisiva privada, mas que, com relação a essa última, há os limites derivados da necessidade da tutela das liberdades asseguradas pelos artigos 21 e 41 da Constituição ${ }^{15}$ (Sentenças n ${ }^{\text {os }} 112 / 1993$ e 420/1994).

\footnotetext{
${ }^{15} \mathrm{O}$ artigo 21 da Constituição Italiana, em seus parágrafos, tutela a liberdade de imprensa, como referido no decorrer deste trabalho, ao passo que o artigo 41 trata da livre iniciativa econômica. (N.T.)
} 
Na Sentença no 155/2002, a Corte entendeu que tal tutela não envolve a discussão da obrigação - puramente modal ou externa - de predispor transmissões de "comunicação política", nas quais o emitente deve assegurar a observância ao contraditório entre as forças políticas e manter uma posição de imparcialidade. Tratar-se-ia, em suma, de mera cessão de espaço, justificada pela necessidade de assegurar um "pluralismo substancial", onde o pluralismo externo se revela ainda insuficiente (abaixo, parágrafo 7.13).

\subsection{As Várias Concepções do Pluralismo e os Limites dele Decorrentes}

O complexo quadro definido pela jurisprudência constitucional deu origem a uma acalorada discussão, no curso da qual foi elaborado o significado do pluralismo informativo, e dos limites que possam surgir com relação ao exercício da liberdade de informação de massmedia.

As doutrinas já delineadas anteriormente (parágrafo 6.3, sumariamente reconduziam ao individualismo, à ideia da "liberdade igual" e à funcionalização) dedicam-se, particularmente, a interpretar o valor constitucional que a Corte definiu, com terminologia oscilante, "interesse geral à informação" ou "direito do cidadão à informação".

1. A primeira tese, que se pode definir como pluralismo (meramente) quantitativo (FOIS), considera tal princípio equivalente ao limite geral antitruste que se pode fazer valer no confronto entre todas as formas de empresa, baseado na disciplina comunitária. Então, ele pode comportar proibições relativas ao abuso da posição dominante e à concentração de empresas, a fim de assegurar a mais ampla concorrência - mas não pode legitimar ainda que na presença de um mercado fechado - uma seleção das empresas em nome da variedade de opiniões, nem determinar limites de conteúdo à informação por eles fornecida. Sob esta ótica, a liberdade de imprensa, dado ao seu caráter puramente individualista, impede de atribuir especial destaque à posição dos destinatários ou ao interesse geral à informação, que seria assegurada, primeira e exaustivamente, pela tutela da concorrência.

Diverge desta conclusão Chiola, segundo o qual o direito à informação deve ser exercido no interesse da sociedade, sendo, portanto, controlável mesmo através do Poder Judiciário. A distinção entre interesse da sociedade e interesse público (que PALADIN define, por outro lado, como meramente nominalista) consente em afastar o controle pelo poder público e, portanto, a funcionalização do direito devido à empresa informativa, atribuindo a esta um estatuto e, por conseguinte, também os limites relativamente à manifestação do pensamento individual.

2. Segundo uma outra tese, o pluralismo invocado pela Corte deve ser compreendido em seu sentido qualitativo, como pressuposto de uma informação efetivamente articulada, na qual sejam representadas vozes e opiniões diversas (CARETTI). 
Nesta posição, a diferença a ser constatada é que, na primeira (pluralismo "quantitativo"), há uma valorização autônoma do interesse geral à informação, em observância às normas constitucionais que, promovendo o livre desenvolvimento da personalidade de cada um, a participação dos cidadãos na gestão da coisa pública, pressupõem a possibilidade de exercitar, em cada campo, escolhas conscientes, além de ensejar a possibilidade de conhecer uma ampla gama de ideias, opiniões, estilos de vida. Na liberdade da empresa de informação estariam legitimamente contidos todos os limites necessários para assegurar a pluralidade e a variedade das ideias e das informações: em particular, os limites derivados de uma disciplina de concentrações e posições dominantes (mais significativa aquela denominada antitruste), bem como a obrigação da autoridade pública de divulgar, através da seleção de empresas interessadas, a mais ampla variedade de opiniões e informações.

A situação subjetiva das empresas resta, portanto, sujeita a severas obrigações: que não comprometem, entretanto, o conteúdo do pensamento expresso, garantindo-se, assim, a liberdade.

3. Segundo uma terceira tese, o correto funcionamento do sistema democrático instaurado pela Constituição implicaria a atribuição, nas mãos dos cidadãos, de fazer uma verdadeira reivindicação, juridicamente tutelada, a fim de obter uma informação completa, objetiva e imparcial (LOIODICE). Esta tese tem por escopo transformar em situação subjetiva individual o interesse geral à informação; mas é, por isso, obrigada a negar, ou a funcionalizar, a liberdade (ativa) de informação.

À tal exigência do cidadão deve corresponder logicamente uma obrigação (direcionada a todos os operadores do setor) que protege o conteúdo do pensamento expresso, ou seja, visando à prestação de uma informação completa, objetiva e imparcial. Disso se segue a possibilidade de se imporem limites, não só externos, mas também internos, ou ainda de conteúdo, no âmbito da atividade informativa e da admissibilidade de controle público direto sobre a mesma.

Em uma palavra, o pluralismo informativo - que nas teses precedentes consiste no instrumento para permitir ao cidadão ouvir vozes e opiniões diversas, obtendo desse conjunto uma informação mais completa e objetiva possível - é, nesta terceira tese, vencido ou absorvido pela pretensão de obter diretamente, de qualquer órgão de imprensa ou radiotelevisivo, uma informação completa e objetiva.

\subsection{O Direito de Informar-se e o Direito de ser Informado}

A tese recém exposta encaixa-se diretamente nas sentenças da Corte, que fazem uma explícita referência ao "direito do cidadão à informação", e em particular à "informação política", em âmbito da atividade radiotelevisiva (Sentenças n ${ }^{\text {os }}$ 826/1988, 420/1994 e 155/2002).

Estas sentenças poderiam levar a pensar que, no entendimento da Corte, o princípio do pluralismo, advindo como limite à liberdade de informação, 
seria convertido em fundamento de uma nova situação subjetiva, que nega a liberdade de informação enquanto tal.

A este respeito, mostra-se necessário fazer uma reflexão aprofundada.

Antes de tudo, é preciso esclarecer a diferença entre o direito de informar-se, que consiste na liberdade de pesquisar e receber as informações que estão a disposição ou colocadas em circulação, e o direito de obter conhecimento ou informação sobre determinados fatos.

O primeiro deles é tutelado diretamente pelo artigo 21 da Constituição, como decorrência lógica da liberdade de manifestação do pensamento: tal regra não teria sentido se os destinatários da mensagem não fossem livres para apreendê-la. As Convenções Internacionais que tutelam especificamente tal direito, vedando aos Estados a colocação de obstáculos à circulação de notícias e informações (abaixo, parágrafo 8.1) nada acrescentam à previsão da nossa Constituição.

Por outro lado, o direito de ser informado sobre determinados eventos (em suma, sobre fatos relevantes à coletividade) constitui expressão do princípio democrático, mas dificilmente se configura como um direito no sentido técnico da palavra.

Por um lado, ele se traduz no princípio da transparência, que rege toda a gestão da coisa pública, compreendendo tanto a tradicional obrigação de publicarem-se os atos de interesse geral quanto as funções de "comunicação institucional" (Lei $n^{\circ} 150$, de 7 de junho de 2000), com as quais a Administração informa aos cidadãos o modo como está conduzindo a sua atividade.

Por outro lado, o direito de ser informado repercute no serviço público radiotelevisivo, que é institucionalmente vinculado à finalidade informativa (além das finalidades cultural e de entretenimento). É lógico que da sociedade concessionária do serviço se deve exigir a oferta de uma informação completa, objetiva e imparcial, subordinando a sua liberdade de informação à realização do interesse público.

A posição da RAI pode, portanto, ser definida como de liberdade funcionalizada, ou, se preferir, de liberdade tout court, sujeita, não obstante com um estatuto que lhe outorga larga autonomia, ao poder de direção da Comissão parlamentar de vigilância.

O problema é que tal exigência não vem tecnicamente configurável como um direito que tenha, no pólo oposto, uma obrigação de conteúdo determinado, passível de coerção por determinação judicial. Pelo senso comum, a seleção das notícias a veicular, entre todas aquelas que diariamente são denunciadas pela agência, assim como a ênfase a ser atribuída a cada uma delas, segundo a ordem de importância, além dos cortes na divulgação, são objeto de escolha por parte do órgão responsável pela informação, sendo impensável submetê-la ao crivo do juiz. 
Em âmbito do serviço público, pode-se e deve-se admitir não um "direito à notícia", mas uma pretensão à completude e à imparcialidade da informação, que por sua natureza, somente se pode dar através do controle dos órgãos públicos competentes. A possibilidade, outorgada aos usuários, de apresentar as suas reivindicações e propostas perante tais órgãos representa, nesta ótica, um elemento fundamental de legitimação do serviço público como um todo.

Assim sendo, deveriam ser valorizados tanto o Conselho Nacional dos usuários, entidade com autoridade para obtenção das garantias nas comunicações, seja através do poder de denúncia atribuído diretamente aos "portadores de interesses difusos constituídos em associações e comitês" em relação à violação de normas de competência da mesma autoridade (artigo $1^{\circ}$, parágrafos 10 e 28, da Lei n²49/1997).

Já no âmbito do serviço privado, a pretensão de ser informado de forma completa, objetiva e imparcial não pode ser postulada, sob pena de negar a existência da liberdade de informação.

Esta regra sofre uma exceção durante o período da campanha eleitoral, quando a pretensão em exame se relaciona diretamente ao correto desenvolvimento do processo democrático. Neste limitado âmbito do cidadão usuário se atribui mais força ao vínculo com a liberdade de voto tutelada pelo artigo 48 da Constituição, que é suscetível de condicionar a liberdade do emitente (abaixo, parágrafo 7.13).

Deve-se, portanto, entender que o "direito à informação" é considerado, pela Corte Constitucional, por sintetizar os múltiplos perfis de uma exigência que é irreprimível no sistema e por enfatizar o vínculo que - ainda que a título diverso - se refere a todos os sujeitos responsáveis pela informação radiotelevisiva.

\subsection{A Disciplina Legislativa das Empresas Editoriais}

Ainda com relação à imprensa e à televisão, a Corte tem dado ênfase ao denominado interesse geral à informação, depreendendo do mesmo a qualificação da imprensa como "serviço objetivamente público, ou ainda de público interesse" (Sentença no 94/1977).

Por outro lado, tal afirmação perde relevo na hipótese de, diferentemente daquela do setor radiotelevisivo, ser tradicionalmente caracterizada pela presença de um considerável número de empresas editoriais.

A realização do pluralismo informativo pode aqui ser colocada em perigo por diversos fatores: pela intervenção estatal, que favorece determinadas empresas em detrimento das demais; dos processos de concentração da coordenação dos mesmos ${ }^{16}$; da drenagem dos recursos publicitários, causado pelo predomínio da televisão, verificado especialmente nos últimos tempos.

\footnotetext{
${ }^{16} \mathrm{O}$ texto original contempla a expressão dai processi di concentrazione delle testate. A palavra testata pode conter vários sentidos. Entretanto, o que o sentido do texto nos dá é da possibilidadade
} 
Relativamente ao primeiro problema, a Corte enfatizou a posição de imparcialidade que deve manter o poder público em relação à imprensa, evitando qualquer intervenção suscetível de traduzir-se, mesmo contra as intenções, em formas de pressão visando a direcionar a imprensa através de objetivos predeterminados (Sentença no 94/1977).

A decisão refere-se a uma lei da região da Sicília que favorecia economicamente a difusão de serviços jornalísticos atinentes às autonomias regionais e à região da Sicília em particular.

Com relação ao terceiro problema, como já referido, a Corte exortou ao legislador a limitar o influxo da publicidade através da televisão, bem como a impedir as coligações entre empresas publicitárias e empresas editoriais e radiotelevisivas.

Quanto ao problema das concentrações, frise-se que houve proposição, logo após a entrada em vigor da Constituição, de nacionalização da editoria, assim como da televisão (CRISAFULLI), considerando a sua natureza de serviço público: mas essa solução foi considerada excessiva (se não vedada pela própria Constituição, devido à previsão única dos denominados limites de transparência, através do artigo 21, quinto parágrafo, que parecem pressupor a efetiva permanência da iniciativa econômica privada).

A lei de reforma da editoria optou, portanto, pela adoção de uma disciplina destinada a limitar a concentração do serviço entre empresas editoriais, bem como a vedar a constituição de posições dominantes. A esse respeito, ressalta-se a diferença entre essa disciplina e as regras antitruste já agora observadas pela União Europeia (adotadas pela Lei $n^{0} 287$ de 10 de outubro de 1990). Tais regras proíbem a concentração, não de forma absoluta, mas somente quando a mesma acarreta dano à eficiência produtiva; além disso, proíbem não somente a formação de uma posição dominante em si, mas apenas o abuso, por parte dessa última, que acaba por causar danos aos concorrentes.

Esta diferença advém do fato de que a disciplina da editoria não se propõe simplesmente a tutelar a concorrência entre empresas editoriais (concorrência esta que estaria satisfeita mesmo pela presença de apenas duas empresas ou grupos editoriais), mas de assegurar o pluralismo informativo, que demanda algo mais, ou seja, a mais ampla possibilidade de acesso ao setor, por parte de um grande grupo de pequenas empresas.

A Lei no 416/1981, por sua vez, proibiu, para o futuro, a constituição de empresas editoriais de caráter público, entendendo que isso seria evidentemente contrastante com o dever de imparcialidade do poder público.

de concentração da coordenação do sistema informativo unicamente pelo Poder Público, como se verá abaixo. Portanto, é de se entender que o significado do termo, nesse contexto, é de direção, coordenação, monopólio do serviço informativo. (N.T.) 
Esta forma de intervenção era, de forma contrária, anteriormente praticada, com o fundamento de incrementar o pluralismo informativo.

A fim de garantir a aplicação imparcial dessas regras, a lei criou um organismo, de todo novo, concebido sob medida para as exigências do setor: o Garante da editoria. Um órgão monocrático, nomeado pelo Presidente da Assembleia entre pessoas de notória independência e imparcialidade. Tal órgão propunha-se como estrutura despida tanto da influência de partidos políticos quanto da vigilância do governo, visando à supervisão de fenômenos de concentração editorial.

Com a Lei $n^{\circ} 223 / 1990$, as suas atribuições referentes às editorias e radiodifusão foram transferidas ao Garante, e com a Lei no 249/1997, à Autoridade pelas garantias nas comunicações. Não obstante a natureza deste último organismo ser substancialmente diversa daquela originária (especialmente pela composição, que volta a ser influenciada pelo Governo e pelos partidos políticos - também pelas atribuições em si, que não mais consistem simplesmente na vigilância imparcial da atuação da lei, mas no controle do sistema de comunicações (abaixo, 7.12), os poderes em matéria de editoria permaneceram com aquele primeiro. Trata-se de poderes limitados à propriedade dos registros da sociedade, à aquisição das informações relativas a compra e venda dos pacotes acionários e ao exercício, perante a autoridade judiciária, do direito de ação visando à nulidade de tais compras, quando as mesmas violem os limites de concentração.

\subsection{A Disciplina Legislativa do Sistema Radiotelevisivo}

Em matéria radiotelevisiva, o legislador permaneceu, por muito tempo, refém de vetos, que impediram tanto a adoção de medidas tempestivas em contraposição às posições dominantes, quanto a elaboração do estatuto da atividade radiotelevisiva.

A Lei $n^{\circ} 112 / 2004$ almeja assinalar a abertura de um novo cenário, no qual "ao advento da tecnologia digital e ao processo de convergência entre a radiotelevisão e outros setores das comunicações interpessoais" (artigo $1^{\circ}$ ) se liga uma diminuição dos graves conflitos com os quais a gestão do setor até agora ocasionou.

Ao tempo que mantém firme o limiar de vinte por cento advindo da jurisprudência constitucional e ratificada pela Lei Maccanico ${ }^{17}$, a lei eleva notavelmente, para as empresas, das sanções antitruste, do momento que assume uma base de cálculo muito mais ampla que a anterior.

\footnotetext{
17 A denominada "Lei Maccanico" (Lei no 249, de 31 de julho de 1997) deve seu nome ao seu proponente, Antonio Maccanico. Tal diploma legislativo instituiu a "Autoridade para as garantias nas comunicações e normas sobre os sistemas de telecomunicações e radiotelevisivo". Propôs-se a fornecer uma completa formulação normativa em matéria comunicação televisiva, além de uma tutela antitruste, em conformidade com o princípio do pluralismo já invocado pela legislação anterior, denominada "Legge Mammi", de 1990 (primeira lei orgânica referente à matéria de radiotelevisão). (N.T.)
} 
Esta base diz respeito, por um lado, à totalidade dos programas televisivos ou radiofônicos e não mais ao total das frequências disponíveis (sob o pressuposto de que, com a técnica digital, cada frequência pode suportar um maior número de transmissões). Por outro lado, ela se refere, não mais apenas à receita arrecadada do setor televisivo, como ocorria na Lei Maccanico, mas também àquela derivada da venda de jornais e periódicos, incluindo livros e fotografias comercializadas em anexo da editoria eletrônica difundida através da internet, além da utilização de obras cinematográficas nas mais diversas formas de fruição do público (sob o pressuposto que todos esses bens retornem em um único mercado, o assim denominado sistema integrado das comunicações, ou sejam, pelos consumidores, substituíveis um pelo outro) (art. 15).

Mesmo definindo a informação radiotelevisiva como um "serviço de interesse geral", a lei submete, por outro lado, a atividade televisiva, em seu todo, à lógica da livre iniciativa, graças à privatização da sociedade com a qual é confiada a gestão do serviço televisivo (sob o pressuposto que o usuário esteja agora em condições de escolher entre a televisão assim denominada generalista e as várias formas de transmissão mediante pagamento) (artigos $6^{\circ}$ e 17 ).

As escolhas assim operadas pelo legislador foram postas em discussão sob vários aspectos.

Em primeiro lugar, observa-se que o uso da televisão digital por parte das famílias italianas é ainda insuficiente (tanto que o encerramento das transmissões em forma analógica - o denominado switch-off - não pode se dar em 31 de dezembro de 2006, como previu o legislador), bem como que, em cada caso, a transferência para o sistema digital não pode garantir, por si, o ingresso de novas empresas no mercado, especialmente diante das possibilidades de reforço que a nova disciplina oferece àquelas já existentes.

Em outras palavras, a premissa tecnológica contida na Lei $n^{0} 112 / 2004$, que entende obsoleto o problema do pluralismo televisivo, seria, na melhor das hipóteses, otimista, como ressaltou a Autoridade para a garantia nas comunicações.

Em segundo lugar, infere-se que o denominado S.i.c. trata da mesma forma produtos que não são verdadeiramente comparáveis e substituíveis entre eles. Na opinião da Autoridade garante da concorrência e do mercado, a noção de "mercado relevante", para fins de aplicação da disciplina antitruste vigente na Europa e na Itália, submete-se a regras diversas e mais restritivas. A este respeito, põe-se o problema de conciliar as disposições em exame com aquelas normativas das diretivas europeias que devem ser aplicadas com fundamento no já citado código de comunicações eletrônicas.

Em terceiro lugar, não se pode duvidar que a privatização da RAl seja compatível com a necessidade de garantir um serviço público adequado, que permanece essencial a grande parte da população (acima, parágrafo 6.1). 
À mesma referência se deve, por outro lado, considerar que na espera de uma completa privatização da R.A.I, a lei atribui ao governo o poder de nomear dois membros do Conselho de Administração da sociedade, entre os quais o presidente (este último subordinado ao parecer favorável de dois terços da Comissão Parlamentar de Vigilância) (art. 20). Isso representa uma evidente violação a ordem expressa da Corte Constitucional, emitida através da Sentença $n^{\circ}$ 225/1974 (acima, parágrafo 7.8), onde se entende como ilegítima, em nome da imparcialidade do serviço público radiotelevisivo, a participação do Executivo na sua gestão.

Em outras palavras, parece que a nova disciplina abandona, de fato, a temática do pluralismo interno, já enfraquecido pela consonância entre as direções editoriais da maior emitente privada e aqueles expressos pela atual maioria governativa no Conselho de Administração da RAl.

O pluralismo externo, mesmo invocado entre os princípios inspiradores da lei, permanece confiado a espontâneos progressos da tecnologia e do mercado, mais que à intervenção do poder público. Não foi por acaso que a Lei $n^{\circ} 112 / 2004$ deixa de reforçar a posição da Autoridade para a garantia das comunicações, que é encarregada de vigiar a observância no seu cumprimento.

Este organismo, criado pela Lei Maccanico, é composto por um Presidente - nomeado pelo Presidente da República, submetido a prévia concordância parlamentar, por maioria qualificada - e por oito comissários, eleitos pela Câmara e Senado, como voto limitado, de forma a assegurar a representação da oposição. A autoridade, que "opera com plena autonomia e com independência de juízo e de valoração" (artigo $1^{\circ}$ da Lei no 249/1997), exerce a competência originariamente atribuída ao Garante em termos de editoria e radiofusão, e é, por outro lado, titular de uma vasta gama de poderes referentes ao regramento das redes e dos serviços de comunicação, que têm a finalidade de abrir o setor à concorrência e também de garantir a observância do pluralismo.

A ação explicada logo acima sobre a denominada Autoridade é demonstrada de forma largamente insatisfatória, não só devido a pressões políticas atribuídas à modalidade de nomeação de seus componentes, mas também ao caráter genérico ou à ambiguidade das disposições que a mesma deve aplicar no exercício da tutela do pluralismo.

Como por outras autoridades independentes que tem por atribuição o dever de assumir importantes decisões com base em indicações legislativas não unívocas, o único reforço praticável seria aquele consistente em precisar, através de lei, os pressupostos e critérios para ação que a Autoridade é chamada a desenvolver na tutela do pluralismo. O parlamento continua a omitir-se nesta tarefa, na esperança de poder atribuir à Autoridade a responsabilidade por decisões que violam as diretrizes desejadas (como na Itália são quam maxime aquelas em matéria televisiva); enquanto a Autoridade, 
ressaltando a contradição entre estas escolhas e sua legitimidade "independente e imparcial", acaba por não decidir, permanecendo em um estado de inércia.

\subsection{A Disciplina da Comunicação Política na Massmedia}

Permanecendo agora no âmbito dos limites ao uso dos meios, deve-se agora tratar do problema da denominada par condicio no uso dos meios de comunicação de massa com a finalidade de veicular propaganda política.

Entre os interesses constitucionalmente relevantes, aos quais o legislador pode subordinar a disciplina dos meios de manifestação do pensamento, a Corte incluiu, há longo tempo, "a paridade de todos os partidos e de todos os cidadãos em um dos momentos essenciais para o desenvolvimento da vida democrática"; paridade que não deve ser, de fato, "obstaculizada pós situações econômicas de desvantagem ou políticas de minoria" (Sentença n 48/1964).

Esta decisão rejeitava a questão de legitimidade constitucional da Lei $n^{\circ} 212$, de 4 de abril de 1956, que obrigava a utilização, para os manifestos de propaganda eleitoral, somente os espaços colocados a disposição pelo órgão competente, que devem ser distribuídos de modo equivalente a todos os contendores.

A partir da Lei $n^{\circ} 81$, de 25 de março de 1983, que se referia somente às eleições locais, e após a Lei $n^{\circ} 515$, de 10 de dezembro de 1993, relativa a todas as campanhas eleitorais, foram introduzidas regras de par condicio também para a propaganda emitida através da imprensa e dos meios radiotelevisivos.

A necessidade de tal disciplina se refere à introdução do novo sistema eleitoral, prevalentemente majoritário, que tem por escopo assegurar a paridade de chances entre os candidatos, tanto no que diz respeito às despesas eleitorais, quanto ao uso dos meios de comunicação de massa, assim como ocorre em outros países de regime democrático.

A matéria foi após disciplinada pela Lei $n^{\circ} 28$, de 22 de fevereiro de 2000, que garante a paridade de acesso aos meios de informação, não só durante a campanha eleitoral e referendária, mas na "comunicação política" em geral.

Por outro lado, a mesma se ocupa principalmente do meio radio televisivo: no que diz respeito à imprensa, é confirmada simplesmente a possibilidade, por parte dos editores, de colocar a disposição, durante a campanha eleitoral, espaços de propaganda, a título gratuito ou oneroso, ressalvada a obrigação de realização de comunicação preventiva, além de oferecer a todos os interessados condições idênticas (art. $7^{\circ}$ ).

No que se refere à televisão, o princípio no qual a lei se baseia é, contrariamente, a gratuidade do acesso, que vale para todos os emitentes, sejam eles entes públicos ou privados (com certa moderação em favor dos emitentes de serviço de rádio e de televisão local) (artigos $2^{\circ}$, parágrafo quarto; artigo $3^{\circ}$, parágrafo sétimo; artigo $4^{\circ}$, parágrafo terceiro, letra "b"). 
As formas de acesso, válidas em qualquer período do ano, são, de um lado, a participação nos programas "de comunicação política" (tribunas políticas, debates, mesas redondas, e, em geral, "qualquer transmissão na qual assuma, em caráter relevante, a exposição de opiniões e avaliações políticas"), e de outro, a transmissão de mensagens políticas de autogestão.

A oferta do primeiro é obrigatória para todas as concessionárias nacionais; de forma diversa, a transmissão de mensagens de autogestão é obrigatória para a concessionária de serviço público, todavia facultativa para os emitentes privados (mas ainda assim, em relação a essas últimas, resta estabelecido que, se decidirem transmiti-las, devem oferecer os espaços em condições de paridade a todos os sujeitos políticos).

A partir da data de convocação dos comícios eleitorais até a data do encerramento da campanha eleitoral, a disciplina torna-se mais rigorosa e, ao mesmo tempo, mais articulada.

Como dito, torna-se mais rigorosa, porque, de um lado, estende a obrigação de paridade de tratamento também aos programas de informação (e não só de "comunicação política"), e, de outro, porque impõe a todos aqueles que participam de qualquer transmissão (em particular, aos diretores e gerentes) a proibição de fazer, ainda que indiretamente, indicações de voto ou de manifestar sua própria preferência política, ou ainda de influenciar, mesmo que de forma sub-reptícia (ou oculta), a livre escolha dos eleitores (artigo $5^{\circ}$ ).

Mais articulada porque visa a assegurar a par condicio não só entre os sujeitos políticos que já tenham uma certa representação, mas também entre estes e os sujeitos que participam pela primeira vez das eleições; além disso, porque o tratamento paritário, dado ao vigente sistema eleitoral, se dirige não só aos partidos políticos singularmente considerados, mas também às coalizões, além das listas que não tenham aderido a nenhuma coalizão.

A realização desta complexa finalidade, que a lei sintetiza no "princípio da paridade de oportunidades" (art. $4^{\circ}$, segundo parágrafo, letra "b"), se dá mediante consulta prévia à Comissão parlamentar de vigilância e da Autoridade garante para as comunicações.

Para o referendo, é previsto, contrariamente, que os espaços sejam repartidos em igual medida entre aqueles favoráveis e aqueles contrários ao quesito referendário.

A lei reitera, ao final, duas específicas proibições, já contidas na disciplina precedente: uma relativa à as atividades de comunicação realizadas pela administração pública, salvo aquelas efetuadas de forma impessoal e indispensável a um desenvolvimento eficaz da sua função; a outra, relativa à divulgação de pesquisas sob o êxito das eleições e sobre as orientações políticas dos eleitores.

Esta última proibição é aplicável nos quinze dias anteriores à data da votação. Fora de tal período, as pesquisas divulgadas devem ser 
publicadas em um adequado espaço, de forma integral, devendo também ser acompanhadas da indicação daquele que as realizou, de quem ordenou a realização, dos critérios observados, do número de pessoas interpeladas e dos métodos de coleta das informações (art. $8^{\circ}$ ).

Como já foi referido (acima, par. 7.8), a nova disciplina da par condicio foi avaliada pela Corte Constitucional através da Sentença n ${ }^{\circ}$ 155/2002.

As obrigações específicas destinadas às empresas no período eleitoral foram justificadas - segundo a jurisprudência que remonta a 1964 - de acordo com a excepcionalidade do momento, que descreve como razoável a exigência de prevenir "qualquer influência, ainda que de forma sub-reptícia, sobre a livre e consciente escolha dos eleitores".

A obrigação de colocar no ar programas de comunicação política, válida no período ordinário, foi interpretada em sentido restritivo, no sentido de que se referia a transmissões "específicas e bastante limitadas no tempo", o que não obriga ao emitente a renunciar à própria identidade política, compelindo-o tão-somente a assegurar o contraditório na participação de todos os entes políticos, mantendo um comportamento neutro. Com base nesta interpretação e do insuficiente desenvolvimento do pluralismo externo, foi considerada como excessiva a imposição de um "pluralismo substancial", destinado a satisfazer o direito à informação política do cidadão.

\section{8. ÂMBITO SUBJETIVO DA GARANTIA CONSTITUCIONAL}

\subsection{Estrangeiros, Pessoas Jurídicas, Titulares de Cargos Públicos}

A liberdade de manifestação do pensamento é textualmente reconhecida a todos, sem distinção entre cidadãos e estrangeiros, diante do caráter universal das liberdades reconhecidas ao homem e à mulher.

Neste aspecto, faz-se necessário considerar, por um lado, que o nosso ordenamento estabelece, em termos gerais, disciplina diferenciada em se tratando de estrangeiros, o que é razoavelmente justificado pela proteção dos interesses constitucionalmente relevantes; por outro lado, que tais disciplinas não podem, portanto, violar as garantias outorgadas à liberdade de pensamento pelas normas de direito internacional, com as quais o ordenamento jurídico italiano se conforma, consoante 0 art. 10 da Constituição.

São relevantes, neste particular, tanto a Declaração Universal dos Direitos Humanos, aprovada pela Assembleia Geral da ONU, quanto a Convenção para a Proteção dos Direitos do Homem e das Liberdades Fundamentais. A primeira tutela, consoante o art. 19, diz respeito à liberdade de opinião e de expressão, incluindo o direito de buscar, receber e transmitir informações e ideias através de qualquer meio e independentemente de fronteiras ${ }^{18}$.

\footnotetext{
${ }^{18} \mathrm{O}$ artigo 19 da Declaração Universal dos Direitos Humanos estabelece que toda a pessoa tem direito à liberdade de opinião e expressão; este direito inclui a liberdade de, sem interferência, ter opiniões e de procurar, receber e transmitir informações e ideias por quaisquer meios e independente de fronteiras. (N.T.)
} 
A segunda reconhece, no artigo 10, a liberdade de opinião e a liberdade de receber e transmitir informações e ideias sem ingerência do poder público ${ }^{19}$ (o art. 11 da Carta dos Direitos Fundamentais da União Europeia faz a fusão dos enunciados dessas duas disposições ${ }^{20}$ ).

Percebe-se que devem ser considerados como titulares das liberdades não só as pessoas físicas, mas também as pessoas jurídicas, em particular as sociedades de capital.

A liberdade não é desfrutada pelos entes públicos, que são institucionalmente vinculados à realização do interesse público. A informação que as mesmas prestam ao cidadão não é uma expressão de liberdade, mas é um dever destinado ao desenvolvimento de suas competências.

O mesmo está a se dizer dos funcionários públicos. Estes, no desenvolvimento de suas tarefas, não exercitam liberdades, mas atividades decorrentes da função. Todos os limites que derivam da observância aos segredos da função, além daqueles que decorrem da disciplina interna da administração, não podem ser considerados como limites restritivos da liberdade de manifestação do pensamento, mas sim como deveres legitimamente atinentes ao cargo ou a função por ele exercida.

Quanto aos membros do Parlamento (e dos conselhos regionais), infere-se que os mesmos gozam, tradicionalmente, de uma liberdade de manifestação do pensamento mais alargada, comparando-se com os demais cidadãos, com base nos artigos 68, primeiro parágrafo ${ }^{21}$ (e 122, quarto parágrafo) da Constituição ${ }^{22}$. Esta tradição possui raízes antigas e provavelmente superadas, mas ainda são consideradas pela praxe do Parlamento, que sempre primou pela imunidade dos votos e das opiniões expressas no exercício da função, concebendo tal condição como uma espécie de prerrogativa pessoal e absoluta.

${ }^{19}$ O artigo 10 da Convenção para a Proteção dos Direitos do Homem e das liberdades Fundamentais contém o seguinte enunciado: Qualquer pessoa tem direito a liberdade de expressão. Este direito compreende a liberdade de opinião e a liberdade de receber ou de transmitir informações ou ideais sem que possa haver ingerência de quaisquer autoridades públicas e sem considerações de fronteiras. O presente artigo não impede que os estados submetam as empresas de radiodifusão, de cinematografia ou de televisão a um regime de autorização prévia. (N.T.)

${ }^{20}$ Art. 11. Liberdade de expressão e informação. 1. Todas as pessoas têm direito à liberdade de expressão. Este direito compreende a liberdade de opinião e a liberddae de receber e de transmitir informações ou ideias, sem que possa haver ingerência de quaisquer poderes públicos e sem consideração de fronteiras. 2. São respeitados a liberdade e o pluralismo dos meios de comunicação social. (N.T.)

${ }^{21} \mathrm{O}$ artigo 68 da Constituição Italiana estabelece que os membros do Parlamento não devem ser chamados a responder por opiniões ou votos emitidos no exercício de suas funções. Também não podem, sem autorização da casa a que pertença serem submetidos a revista pessoal ou domiciliar, nem mesmo podem ser presos ou privados, por qualquer outra forma, de sua liberdade pessoal, se não em cumprimento de condenação transitada em julgado, ou sejam flagrados cometendo um delito para qual se prevê obrigatoriamente a prisão em flagrante. (N.T.)

${ }^{22} \mathrm{O}$ quarto parágrafo do artigo 122 da Constituição Italiana prevê que os conselheiros regionais não podem ser chamados a responder por suas opiniões expressas e pelos votos dados no exercício de suas funções. (N.T.) 
Hoje, a jurisprudência da Corte Constitucional admite, entretanto, traçar uma distinção operacional, não apenas ideal, entre opiniões expressadas no exercício das funções (ainda que em termos gerais) e opiniões expressadas a título pessoal. A primeira consiste em uma emanação da atividade políticoparlamentar, não podendo dar lugar à responsabilização, ressalvando-se, obviamente, a responsabilidade política do parlamentar perante seus eleitores. A segunda, ao contrário, deve ser considerada como propriamente exercício da manifestação da liberdade do pensamento, e, enquanto tal, submete-se a todos os limites a esta aplicáveis. Em particular, ela não pode ir ao ponto de violar a honra e a reputação de terceiros, como a Corte Constitucional expressamente declarou (Sentença $n^{0}$ 1150/1988).

A tutela específica do artigo 68 exprime o fato de que pertence à Câmara perquirir se a opinião expressada se enquadra no exercício das funções parlamentares, estando, portanto, sujeita à imunidade: tal competência do Parlamento está, por outro lado, sujeita ao crivo da Corte Constitucional. Possui a Corte investidura, em sede de conflito de atribuições entre poderes, em caso de um juiz que considere a decisão parlamentar ilegitimamente lesiva às funções jurisdicionais (e, portanto, indiretamente, do direito à tutela do cidadão lesado por opinião expressada por parlamentar). A Corte já declarou que não se pode entender como imune a opinião emitida por parlamentar fora de sua sede institucional (Sentença $\mathrm{n}^{\circ}$ 10/2000).

Também os membros do Conselho Superior da Magistratura gozam de imunidade, imunidade esta, entretanto, restrita às opiniões que dizem respeito ao objeto da discussão. A Corte Constitucional, com a Sentença $n^{\circ} 141 / 1983$, entendeu que tal disposição não viola o princípio da igualdade entre os cidadãos. Isso porque, enquanto contida em uma disposição de lei ordinária, fornece meios para a necessária aplicação da previsão constitucional do Conselho Superior (art. 104) e ao efetivo desempenho de suas funções.

Para o Chefe de Estado, a Corte de Cassação (seção III, 27 de junho de 2000, m. 8734) entendeu que a sua o ato de externar sua opinião é protegido pela imunidade constante do artigo 90 da Constituição ${ }^{23}$, quando for relacionado ao exercício de suas funções. Caso contrário, ser-Ihe-á imposta a responsabilidade advinda do exercício da liberdade de manifestação do pensamento.

\subsection{O Estatuto do Jornalista}

Quanto à liberdade do jornalista, tem-se que a mesma se configura de forma autônoma, no sistema italiano, através da Lei $n^{\circ} 69$, de 3 de fevereiro de 1963, enquanto exercício profissional do direito de crônica e de crítica,

\footnotetext{
${ }^{23} \mathrm{O}$ artigo 90 da Constituição Italiana estabelece que o Presidente da República não é responsável por atos praticados no exercício de suas funções, exceto por ato considerado alta traição ou atentado à Constituição.
} 
através dos meios de informação. A citada lei se aplica àqueles que são devidamente inscritos no órgão competente, sendo, pois, sujeitos à fiscalização pelo Conselho da Ordem dos Jornalistas.

Esta disciplina carece de legitimidade constitucional em relação ao artigo 21 da Constituição, tanto por violação ao direito de todos de manifestar o pensamento através de qualquer meio, seja pela violação da liberdade de pensamento dos jornalistas.

A Corte Constitucional entendeu, todavia, que a filiação à Ordem não é condição necessária para o desempenho da atividade de jornalista, quando esta tiver caráter não-profissional; e que a obrigação de inscrição não limita a liberdade do jornalista, no momento em que o Conselho, por um lado, não pode exercer nenhum tipo de controle sobre o conteúdo do escrito e, por outro, pode, ao invés, desempenhar uma função de garantia da liberdade e dos interesses dos jornalistas, quando esses confrontarem o poder econômico detido pelos editores (Sentenças $n^{\text {os }} 11$ e 120/1968).

Ambos os argumentos foram alvo de severas críticas. Primeiramente, porque é de todo irreal supor que o cidadão comum tenha acesso ao uso do meio; em segundo lugar, porque o Conselho possui, quando muito, poder de seleção dos aspirantes jornalistas, não tendo nenhum poder de tutela econômica da categoria (poder este que detém o sindicato).

A problemática constitucional relativa ao status do jornalista diz respeito à necessidade de conciliar o mais amplo exercício do direito de crônica com a tutela dos direitos de terceiros, de um lado, e com observância às diretrizes que movem a empresa editorial na qual o jornalista trabalha, de outro.

Trata-se, respectivamente, das temáticas conhecidas sob o nome de liberdade de imprensa e liberdade na imprensa.

1. A específica tutela do direito de crônica e de crítica do jornalista se identifica com a elaboração jurisprudencial que the reconheceu uma posição privilegiada em comparação com os limites comuns da liberdade de manifestação do pensamento: este privilégio não lhe é outorgado em caráter absoluto, como em outras circunstâncias (vide parágrafo 3), existindo certas condições que sua obra deve respeitar.

Em particular, aplicando o artigo 51 do Código Penal, que exclui a antijuridicidade do fato cometido no exercício de um direito, conclui-se que o jornalista não deve ser incriminado por atos cometidos no exercício do direito de crônica: desde que as notícias divulgadas sejam consideradas, ao menos, subjetivamente verídicas (ou tenham sido objeto de detalhada verificação); desde que atendam a um real interesse de conhecimento por parte do público (que não sirvam somente para satisfazer a mera curiosidade ou "fofocas"); e desde que sejam veiculadas de forma polida ou moderada (que não sejam injustificadamente repletas de insinuações, combinações sugestivas ou expressas em um tom desproporcionalmente chocante). 
Neste problema se envolve também a questão da sátira, seja pela caricatura ou representação exagerada e deformada de um fato ou de uma pessoa. Esta é, por outro lado, desvinculada, na jurisprudência, da função informativa e remetida, por outro lado, à tutela do humorismo, com forma de tutela à liberdade artística (BEVERE-CERRI).

Tais critérios: continência material (ou interesse público na notícia) e continência formal, sintetizadas no "decálogo" declarado pela Corte de Cassação (I Seção Cível, de 18 de outubro de 1984, n 5259). Tais critérios são passíveis de contestação, pelo seu caráter genérico e indefinido, que ensejariam uma aplicação variável.

Por outro lado, eles tentam assegurar a mais ampla liberdade ao jornalista, visando também à sua responsabilização pelas consequências advindas da sua atividade, efetuando uma análise casuística do equilíbrio entre o direito de crônica e outros bens constitucionalmente envolvidos.

Na verdade, a função desenvolvida pela jurisprudência se fez necessária diante da carência de mecanismos capazes de prevenir (em vez de ter que dirimir posteriormente) o conflito entre o direito de crônica e direitos de terceiros.

Inadequada é, de fato, a previsão do artigo 57 do Código $\mathrm{Penal}^{24}$, que atribui ao diretor a responsabilidade penal por tudo aquilo que é publicado, atribuindo-lhe, na prática, poder de vida ou morte em qualquer artigo escrito por um jornalista.

O legislador republicano limitou-se a atenuar a posição do diretor, estabelecendo que se the poderia excluir a responsabilização, caso demonstrasse a impossibilidade de ter tido acesso ao artigo publicado. Entretanto, isso não elide o caráter autoritário desta disposição.

Impraticável parece também a via da autodisciplina de categoria, adotada com sucesso por outros ordenamentos, até quando a nova lei sobre proteção de dados pessoais (ver artigo 139 Decreto Legislativo $n^{\circ}$ 196/2003) não a tornou obrigatória, atribuindo ao Garante poderes prescritivos em âmbito do Conselho Nacional da Ordem dos Jornalistas.

Foi assim aprovado o Código de deontologia relativo ao tratamento dos dados pessoais no exercício da atividade jornalística, que, pela primeira vez, disciplina, com eficácia normativa erga omnes, os limites impostos ao direito de crônica pela tutela da dignidade da pessoa humana.

A coleta e a transmissão de informações sobre pessoas com fundamento na liberdade de manifestação do pensamento é, com base na lei, permitida

\footnotetext{
${ }^{24}$ Art. 57 do Código Penal Italiano: Sem prejuízo da responsabilidade do autor da publicação e, exceto em casos de concorrência, o diretor ou vice-diretor, que deixa de exercer o controle necessário sobre o conteúdo do periódico, de forma a impedir que através da publicação sejam cometidos crimes, é punido, a título de culpa, se um crime é cometido, com a pena estabelecida por tal delito, com redução que não pode exceder a um terço.
} 
como bem de maior amplitude, com relação a qualquer outro "tratamento de dados pessoais", desde que seja relativa a fatos de interesse público e se limitem ao essencial (excluindo, em princípio, notícias relativas aos hábitos sexuais e ao estado de saúde, ressalvando-se o fato de tratar-se de pessoas que se revestem de uma posição de particular importância social ou pública).

Em observância ao princípio da igualdade, a disciplina em exame se aplica a qualquer um que exercite, ainda que ocasionalmente, a liberdade tutelada pelo artigo 21 da Constituição e não contribui, portanto, a alimentar o status especial do jornalista.

Reserva-se a este último, em vez, a norma do artigo 200, terceiro parágrafo, do novo Código de Processo Penal Italiano, o direito de não revelar a própria fonte, ou seja: o nome das pessoas que lhe forneceram informações em caráter de confiança (direito que é essencial para a finalidade de coleta de notícias).

A diferença para com outros segredos profissionais (acima, parágrafo 7.5), o segredo do jornalista não é absoluto, mas pode ser limitado pelo juiz, onde a indicação da fonte se mostra indispensável para fins de prova do crime e do acertamento da verdade das notícias a ele relativas.

2. Quanto à liberdade na imprensa, ou ainda à relação entre os editores, o diretor é considerado longa manus do interno, e, quanto aos jornalistas, ela representa um problema largamente controverso e provavelmente insolúvel, se não se refere à concreta realidade da empresa editorial.

A contraposição abstrata entre a liberdade de manifestação do pensamento do jornalista, de um lado, e o poder da propriedade de fixar as diretrizes editoriais de outro, não pode ser resolvida simplesmente eliminando um dos dois pólos, como já se tem tentado fazer.

É indubitável que o órgão de informação constitui uma única entidade com a qual todos devem colaborar seguindo uma diretriz comum, sob pena de perder sua razão de ser: a isso ressalva-se a necessidade de articular em concreto os momentos caracterizadores de tal colaboração.

No momento da fundação da empresa, é evidentemente o editor quem assume os riscos da mesma, estabelece as linhas, escolhe os colaboradores mais idôneos a dar-lhe andamento (ele pode não desenvolver pesquisa sobre a opinião dos jornalistas que pretende contratar, em oposição ao veto fixado pelo Estatuto dos Trabalhadores).

Em seguida, quando a coletividade editorial constitui-se e trabalha com base em um projeto comum assim estabelecido, a liberdade do editor não pode mais ser considerada absoluta. A esse respeito, entende-se, por exemplo, que o editor seja compelido a permanecer fiel à linha inicialmente escolhida, uma vez que a mesma tenha sido objetivada no tempo, a menos que o comitê de redação consinta na alteração (PACE). 
O legislador não afrontou, assim, o argumento, autorizando a contratação coletiva. No momento, a única regra referente a esta matéria é aquela contida no artigo 32 do contrato coletivo nacional dos jornalistas (denominada cláusula de consciência), segundo a qual o jornalista é livre para rescindir antecipadamente o seu contrato de trabalho, sem perder o direito às verbas rescisórias, quando o editor imponha ao jornal uma radical alteração da linha anteriormente adotada.

\section{REFERÊNCIAS BIBLIOGRÁFICAS}

BALDASSARRE, A. Diritti Inviolabili, in Enc. Giur., XI, 1989.

BALDASSARRE, A. Libertà di Stampa e Diritto all'informazione nelle Democrazie Contemporanee, in Pol. Del. Dir., 1986.

BALDASSARRE, A. Le Ideologie Costituzionali dei Diritti di Liberta, in Dem. dir., 1976.

BARBERA, A.; COCOZZA, F.; CORSO, G. Le Libertà dei Singoli e delle Formazioni Sociali, in G. AMATO; A. BARBERA. Manuale di Diritto Pubblico, vol. I, V ed. Bologna, 1997.

BARILE, P. Libertà di Manifestazione del Pensiero, in Enc. Dir., XXIV, 1974.

BARILE, P.; ZACCARIA, R. Rapporto '93 sui problemi giuridici della radiotelevisone italiana, Torino, 1994.

BARILE, P.; GRASSI, S. Informazione (libertà di), in Nss Dig. It. App. IV, 1983.

BARILE, P.; DE SIERVO, U. Sanzioni contro il Fascismo e il Neofascismo, in Nss. Dig. It. XVI, 1969.

BEVERE, A.; CERRI, A. I/ Diritto di Informazione e i Direitti della Persona, Milano, 1995. BÖCKENFÖRDE, E. W. The Basic Rights: Theory of Interpretation (1974), in State Society and Liberty, New York Oxford 1991.

BÖCKENFÖRDE, E. W. Safeguarding Liberty in relation to Social Power (1975), ivi.

BOGNETTI, G. Costituzione, Televisione e Legge antitrust, Milano, 1996.

BOLLINGER, L. La Società Tollerante (1986), trad. it. Milano, 1992.

BORRELLO, R. Interrogativi sulla Disciplina della par Condicio nel nuovo assetto dela Sistema Radiotelevisivo Italiano, in MANETTI M. (a cura di), Europa e Informazione, cit.

CARETTI, P. Diritto dell'informazione e della Comunicazione, III ed., Bologna, 2004.

CARETTI, P. Art. 10 in S. BARTOLE- B; CONFORTI-G. RAIMONDI (a cura di), Commentario alla Convenzione Europea per la Tutela dei Diritti dell'Uomo e delle Liberta Fondamentali, Padova, 2001.

CARETTI, P. Radiotelevisione, in Enc. dir. atual., I. 1997.

CERRI, A. Arte e Scienza (libertà di), in Enc. Giur., III, 1998.

CHIOLA, C. Manifestazione del Pensiero, in Enc. Giur., XIX, 1990.

CHIOLA, C. L'informazione nella Costituzione, Padova, 1973.

CLARICH, M.; CARTEI, G. F. Il Codice delle Comunicazioni Elettroniche, Milano, 2004.

COSTANZO, P. Informazione nel Diritto Costituzionale, in Dig. disc. pubbl., VIII, 1993.

COSTANZO, P. Stampa (libertà di), in Dig. disc. pubbl., XIV, 1999.

COSTANZO, P. Internet (diritto pubblico), in Dig. disc. pubbl., atual., 2000. 
CRISAFULLI, V. Problematica della Libertà di Informazione, in II Politico, 1964.

CUNIBERTI, M.; VIGEVANI, E. La Riforma del Sistema Televisivo, Torino, 2004.

CUOMO, G. Libertà di stampa e impresa giornalistica nell'ordenamento Costituzionale Italiano, Napoli, 1956.

DE SIERVO, U. Stampa (dir. pubbl.), in Enc. dir., XLIII, 1990.

DE SIERVO, U. Informazione e Dignità della Persona, in ${ }^{\circ}$ L. CARLASSARE (a cura di), La Comunicazione del Futuro e i Diritti delle Persone, Padova, 2000.

DI GIOVINE, A. I Confini della Libertà di Manifestazione del Pensiero, Milano, 1988.

DI GIOVINE, A. Libertà di Informazione - O potere?, in M. BOVERO (a cura di), Quale Libertà, Roma-Bari, 2004.

ESPOSITO, C. La Libertà di Manifestazione del Pensiero nell'ordinamento Italiano. Milano, 1958.

FIORE, C. I Reati di Opinione, Padova, 1972.

FOIS, S. Principi Costituzionali e Libera Manifestazione del Pensiero, Milano, 1957.

FOIS, S. La Libertà d'informazione, Rimini, 1991.

FOIS, S. Informazione e Diritti Costituzionali, in Dir. inf., 2000.

GENTILI, A. La Disciplina Antitrust. Telecomunicazioni, Editoria, Radiotelevisione fra Disciplina Generale e Disciplina Specifica, in R. ZACCARIA (a cura di), Informazione e Telecomunicazione, in Trattato di Diritto Amministrativo direto de G. Santaniello, Padova, 1999.

GRANDINETTI, O. La Radiotelevisione, In S. CASSESE (a cura di), Trattato di Diritto Amministrativo, t. III, Milano, 2003.

GRASSI, S. La Commissione Parlamentare per l'indirizzo e la Vigilanza Sulla RAI: prospettive di riforma, in R. ZACCARIA (a cura di), Informazione e Telecomunicazione, cit.

HÄBERLE, P. II Duplice Carattere dei Diritto Fondamentali: l'aspetto di diritto individuale e quello istituzionale, in Le libertà fondamentali nello Stato costituzionale, trad. it. A cura di P. Ridola, Roma, 1993.

LIPARI, N. Libertà di Informare o Diritto ad Essere Informati?, in Dir. radiodiff., 1978.

LIPARI, N.; BOCCHINI, E.; STAMMATI, S. (a cura di), Sistema Radiotelevisivo e Autorità per le Comunicazioni, Padova, 2000.

LOIODICE, A. Informazione (Diritto alla), in Enc. dir., XXI, 1971.

LUCIANI, M. La Libertà di Informazione nella Giurisprudenza Costituzionale, in Pol. del dir., 1989.

MANETTI, M. (a cura di), Europa e Informazione, in Quaderni rass. dir. pubbl. eur., 2004.

MANETTI, M. L'incitamento dell'odio Raziale tra Realizzazione dell'aguaglianza e Difesa dello Stato, in Studi in onore di Gianni Ferrara, II, Torino, 2005.

MAZZIOTTI, M. Appunti sulla libertà d'informazione nell'ordinamento italiano, in Scritti Crisafulli, II, Padova, 1995.

MAZZIOTTI, M. Diritto all'imagine e Costituzione, in Giur. cost., 1970.

MILL, J. S. La Libertà (1859), trad. it. P. Gobetti,Torino, 1925.

MILTON, J. Aeropagitica (1644), trad. it. S. Breglia, Bari, 1933. 
MORBIDELLI, G.; DONATI, F. (a cura di), Comunicazioni: verso il diritto della convergenza, Torino, 2003.

MORTATI, C. La Libertà di Stampa in Regime Democrático (1947), in Racolta di Scritti, vol. III, Milano, 1972.

NANIA, R. La Corte Suprema, la libertà di espressione delle idee ed il pubblico flag burning, in Giur. cost., 1990.

NOWAK, M. Politische Grundrechte, Wien-New York, 1988.

NUVOLONE, P. II Diritto Penale della Stampa, Padova, 1971.

PACE, A.; MANETTI, M. Art. 21, in Commentario della Costituzione, a cura di A. Pizzorusso, Bologna, 2006.

PACE, A. Libertà, Pluralismo e Autorità nella Disciplina Radiotelevisiva e delle Telecomunicazione, in Studi in onore di Umberto Pototschnig, II, Milano, 2002.

PACE, A. Comunicazioni di Massa, in Enc. scienze sociali, II, 1992.

PACE, A. Il Concetto di Ordine Pubblico nella Costituzione, in Archivio giuridico, 1963.

PALADIN, L. Libertà di Pensiero e Libertà d'informazione: le problematiche attuali; in Quad. cost., 1987.

PALADIN, L. Problemi e Vicende della Libertà d'informazione nell'ordinamento Giuridico Italiano, in AA.VV., La Libertà d'informazione, Torino, 1979.

PIZZORUSSO, A. Libertà di Pensiero - Opportunità e rischi, in M. BOVERO (a cura di), Quale libertà, cit.

POPPER, K. R. Cattiva Maestra Televisione, Milano, 1994.

RIMOLI, F. La Libertà dell'arte nell'ordinamento Italiano, Padova, 1992.

RODOTÀ, S. Tecnopolitica: la democrazia e le nuove tecnologie della comunicazione, Roma-Bari, 1997.

SANDULLI, A. M. La Libertà d'informazione, in AA.VV., Problemi dell'informazione, Milano, 1979 e in Dir. radiodiff., 1977.

SARTORI, G. Homo Videns. Televisione e post-pensiero, Roma-Bari, 1998.

SCHLAICH, K. Neutralität als Verfassungrechtliches Prinzip, Tübingen, 1972.

SCHMITT, C. Dottrina della Costituzione (1928), trad. it. A cura di A. Caracciolo, Milano, 1984.

SMEND, R. Das Recht der freien Meinungaüsserung (1928) in Staatrechtliche Abhandlungen, II, ed., Berlin, 1968.

STANCATI, P. Manifestazione del Pensiero e Informazione tra Libertà e Funzione, Rende, 2002.

ZACCARIA, R. Diritto dell'informazione e della Comunicazione, IV ed., Padova, 2004.

ZAGREBELSKY, G. Questioni di Legitimità Costituzionale della lege 3 febbraio 1963, $n^{\circ} 69$, istitutiva dell' Ordine dei Giornalisti, in Giur. cost., 1968.

ZENO-ZENCOVICH, V. La Libertà d'espressione, Bologna, 2004. 